Nevada

Environmental

Restoration

Project

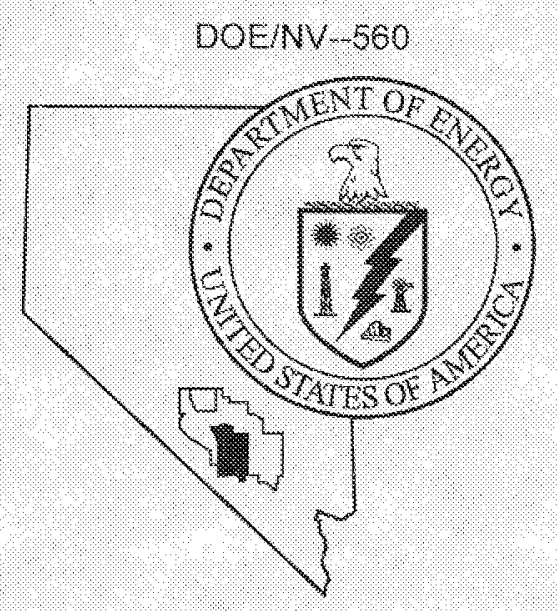

\title{
Corrective Action Plan for Corrective Action Unit 340: Pesticide Release Site Nevada Test Site, Nevada
}

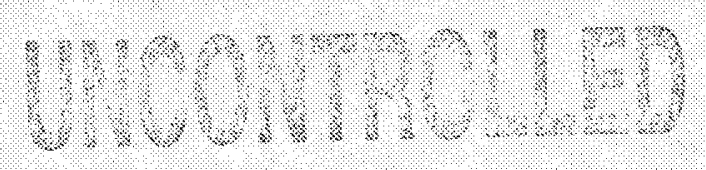

Controlled Copy No.:

Revision: 0

September 1999

Distribution A - Approved for public release: further dissemination unimited

Environmental Restoration

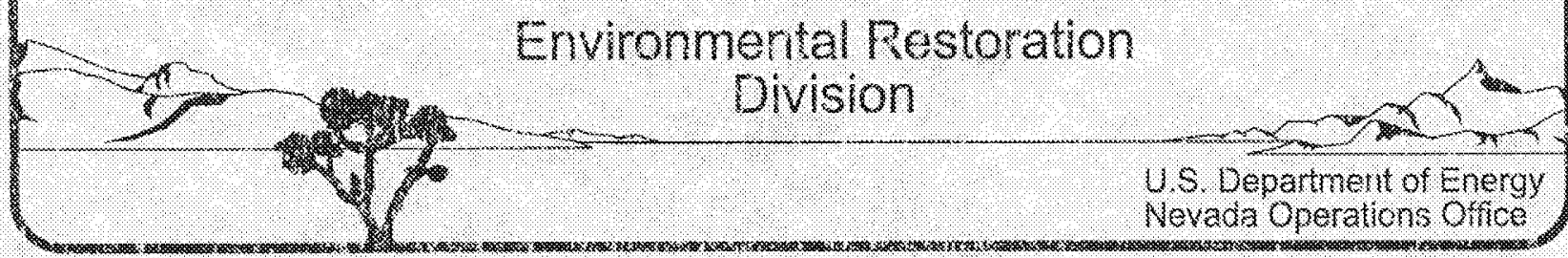


Avalable to the public from:

U. S. Department of Commerce

National Technical Information Service

5285 Port Royal Road

Springfield, VA 22161

(703) $487-4650$

Available electronically at http://www doe gov/bridge. Avalable to the U.S. Department of

Energy and its contractors in paper from:

U.S. Department of Energy

Office of Scientific and Technical Information

P.0. Box 62

Oak Ridge, TN $37831-0062$

(423) 576-8401.

Reference herein to any specific commercial product, process, or service by trade name, trademark, manufacturer, or otherwise, does not necessarily constitute or imply its endorsement. recommendation, or lavoring by the U.S. Government or any agency thereof or its contractors or subcontractors. 


\section{CORRECTIVE ACTION PLAN FOR CORRECTIVE ACTION UNIT 340: PESTICIDE RELEASE SITE, NEVADA TEST SITE, NEVADA}

Controlled Copy No.:

Revision 0

September 1999

Prepared for the U.S. Department of Energy

Nevada Operations Office under Contract No. DE-AC08-96NV11718 
THIS PAGE INTENTIONALLY LEFT BLANK 
DOE/NV--560

\section{CORRECTIVE ACTION PLAN FOR CORRECTIVE ACTION UNIT 340: PESTICIDE RELEASE SITE, NEVADA TEST SITE, NEVADA}

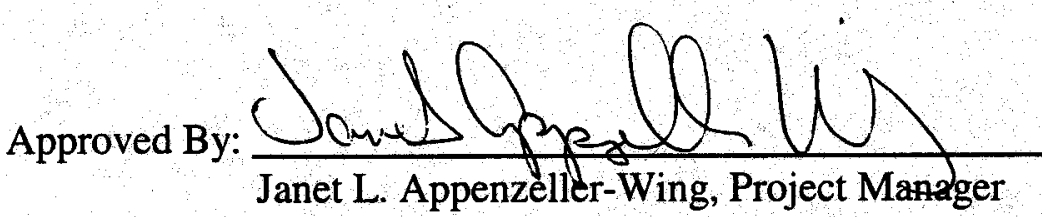
Industrial Sites Project

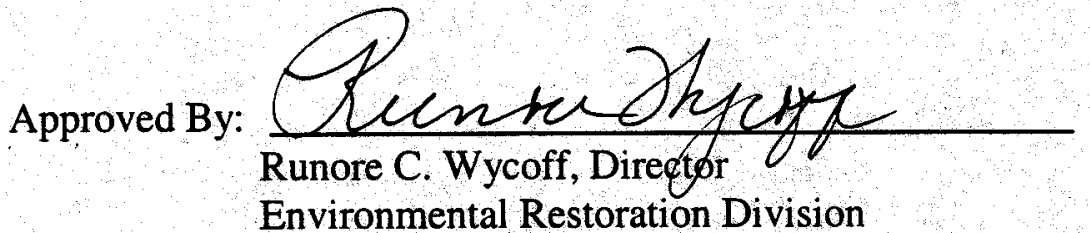

Date:

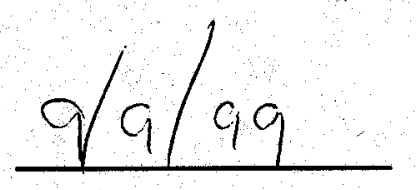

Date: 
THIS PAGE INTENTIONALLY LEFT BLANK 


\section{TABLE OF CONTENTS}

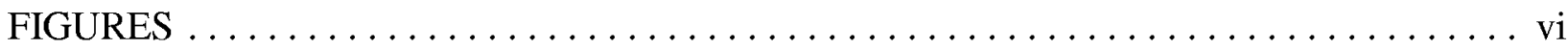

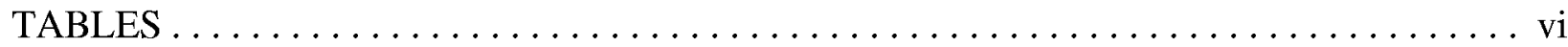

ACRONYMS AND ABBREVIATIONS $\ldots \ldots \ldots \ldots \ldots \ldots \ldots \ldots \ldots \ldots \ldots$ vii

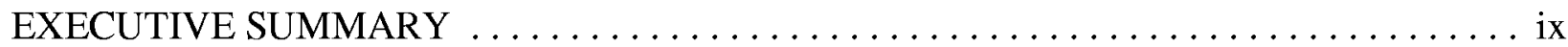

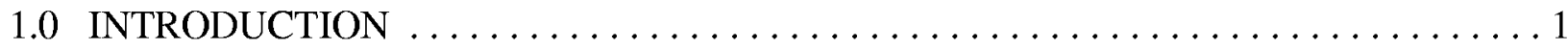

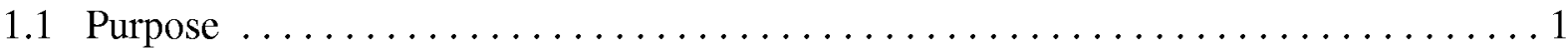

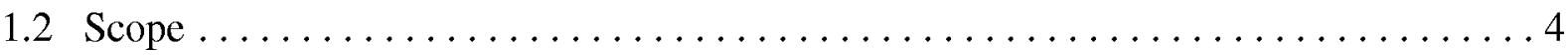

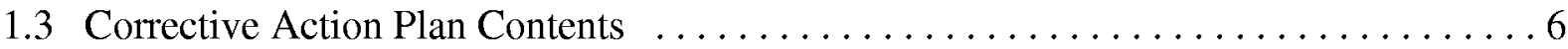

2.0 DETAILED STATEMENT OF WORK $\ldots \ldots \ldots \ldots \ldots \ldots \ldots \ldots \ldots \ldots \ldots \ldots$

2.1 Approved Alternative Implementation $\ldots \ldots \ldots \ldots \ldots \ldots \ldots \ldots \ldots \ldots \ldots \ldots \ldots \ldots \ldots \ldots \ldots$

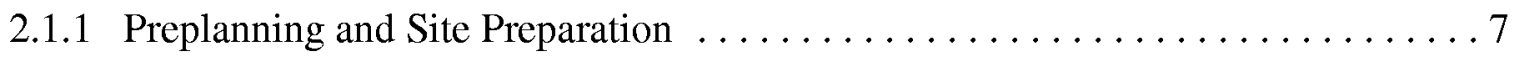

2.1.1.1 Site-Specific Health and Safety Plan/Hazard Analysis . . . . . . . . . 7

2.1.1.2 Field Management Plan . . . . . . . . . . . . . . . . 8

2.1.1.3 National Environmental Policy Act Documentation . . . . . . . . . 8

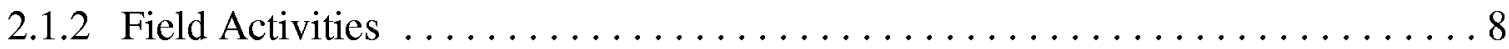

2.1.2.1 Excavation of the Soil Containing Hazardous Chlordane . . . . . . . . 8 8

2.1.2.2 Excavation of the Soil Impacted with Nonhazardous Pesticides . . . . . 10

2.1.2.3 Decontamination of Equipment ................. 10

2.1.2.4 Backfilling and Grading of the Site . . . . . . . . . . . . 10

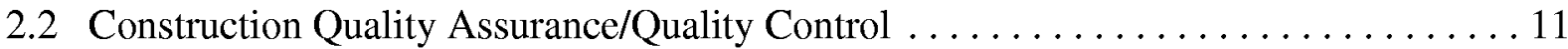

2.3 Waste Management . . . . . . . . . . . . . . . . . . . . . . 11

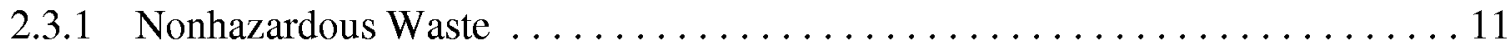

2.3.2 Hazardous Waste . . . . . . . . . . . . . . . . . . . . . 15

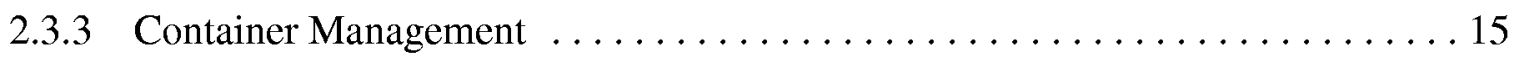

2.3.4 Site Control . . . . . . . . . . . . . . . . . . . . . . 16

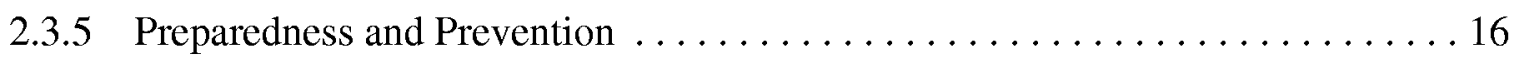

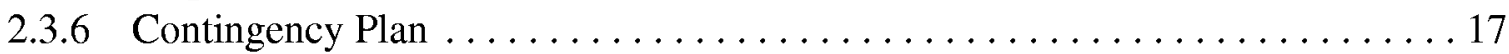

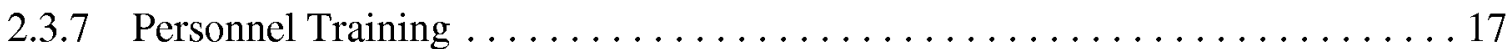

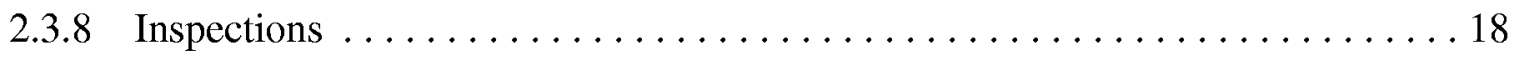

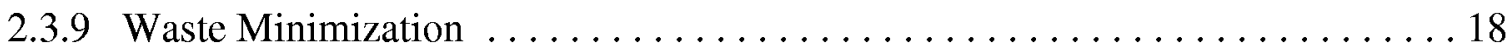

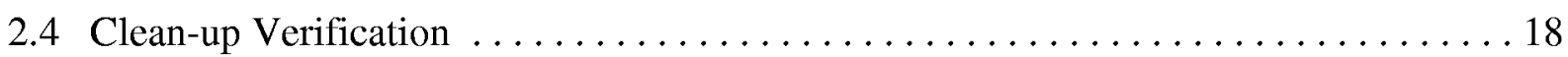

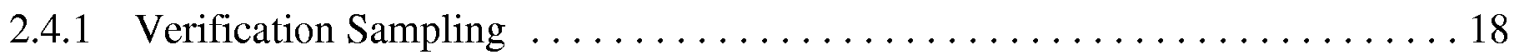

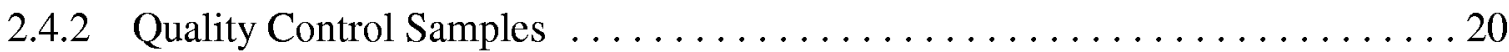

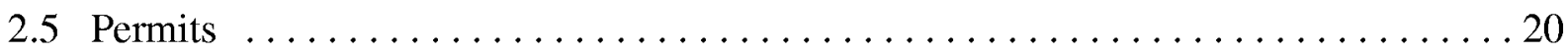

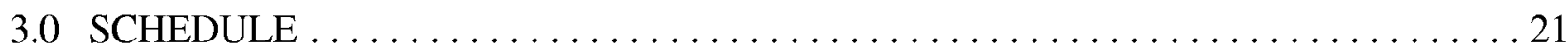

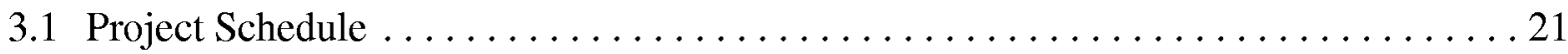

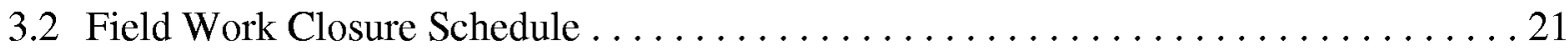




\section{TABLE OF CONTENTS (continued)}

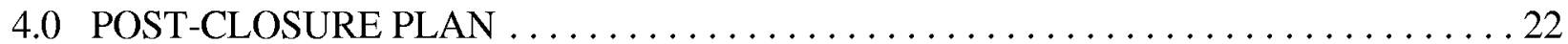

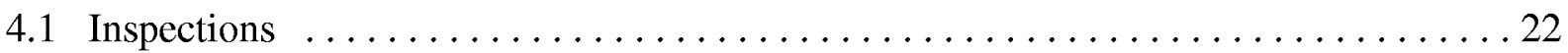

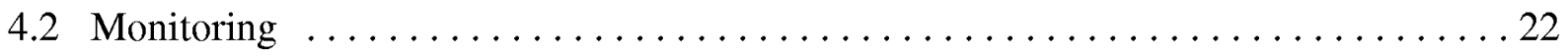

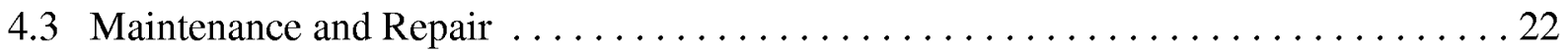

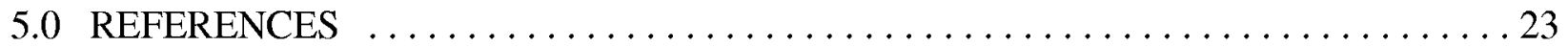

\section{APPENDICES}

Appendix A: Approval Documentation for Nonhazardous Waste Disposal

Appendix B: Contingency Plan

Appendix C: Project Organization

Distribution List

\section{FIGURES}

Figure 1 - CAU 340 Site Location Map $\ldots \ldots \ldots \ldots \ldots \ldots \ldots \ldots \ldots \ldots \ldots \ldots \ldots \ldots \ldots \ldots$

Figure 2 - CAU 340 Proposed Site Layout Map $\ldots \ldots \ldots \ldots \ldots \ldots \ldots \ldots$

Figure 3 - Proposed Clean-up Verification Sample Location $\ldots . \ldots \ldots \ldots \ldots$

\section{TABLES}

Table 1 - Proposed Remediation Standards for CAU $340 \ldots \ldots \ldots \ldots \ldots \ldots$

Table 2 - Management of Various Waste Types to be Produced at the Pesticide Release Site . 12

Table 3 - Pesticide Release Site Verification Sampling Parameters . . . . . . . . . . . . . 19 


\section{ACRONYMS AND ABBREVIATIONS}

\begin{tabular}{|c|c|}
\hline $\mathrm{BN}$ & Bechtel Nevada \\
\hline CADD & Corrective Action Decision Document \\
\hline CAIP & Corrective Action Investigation Plan \\
\hline CAS & Corrective Action Site \\
\hline CAU & Corrective Action Unit \\
\hline CFR & Code of Federal Regulations \\
\hline DOE & U.S. Department of Energy \\
\hline DOE/NV & U.S. Department of Energy, Nevada Operations Office \\
\hline $\mathrm{EC}$ & Emergency Coordinator \\
\hline EPA & U.S. Environmental Protection Agency \\
\hline ER & Environmental Restoration \\
\hline FFACO & Federal Facility Agreement and Consent Order \\
\hline $\mathrm{ft}$ & foot \\
\hline $\mathrm{ft}^{2}$ & square foot \\
\hline gal & gallon \\
\hline $\mathrm{Ha}$ & Hazard Assessment \\
\hline $\mathrm{L}$ & liter \\
\hline $\mathrm{m}$ & meter \\
\hline $\mathrm{m}^{2}$ & square meter \\
\hline $\mathrm{m}^{3}$ & cubic meter \\
\hline
\end{tabular}




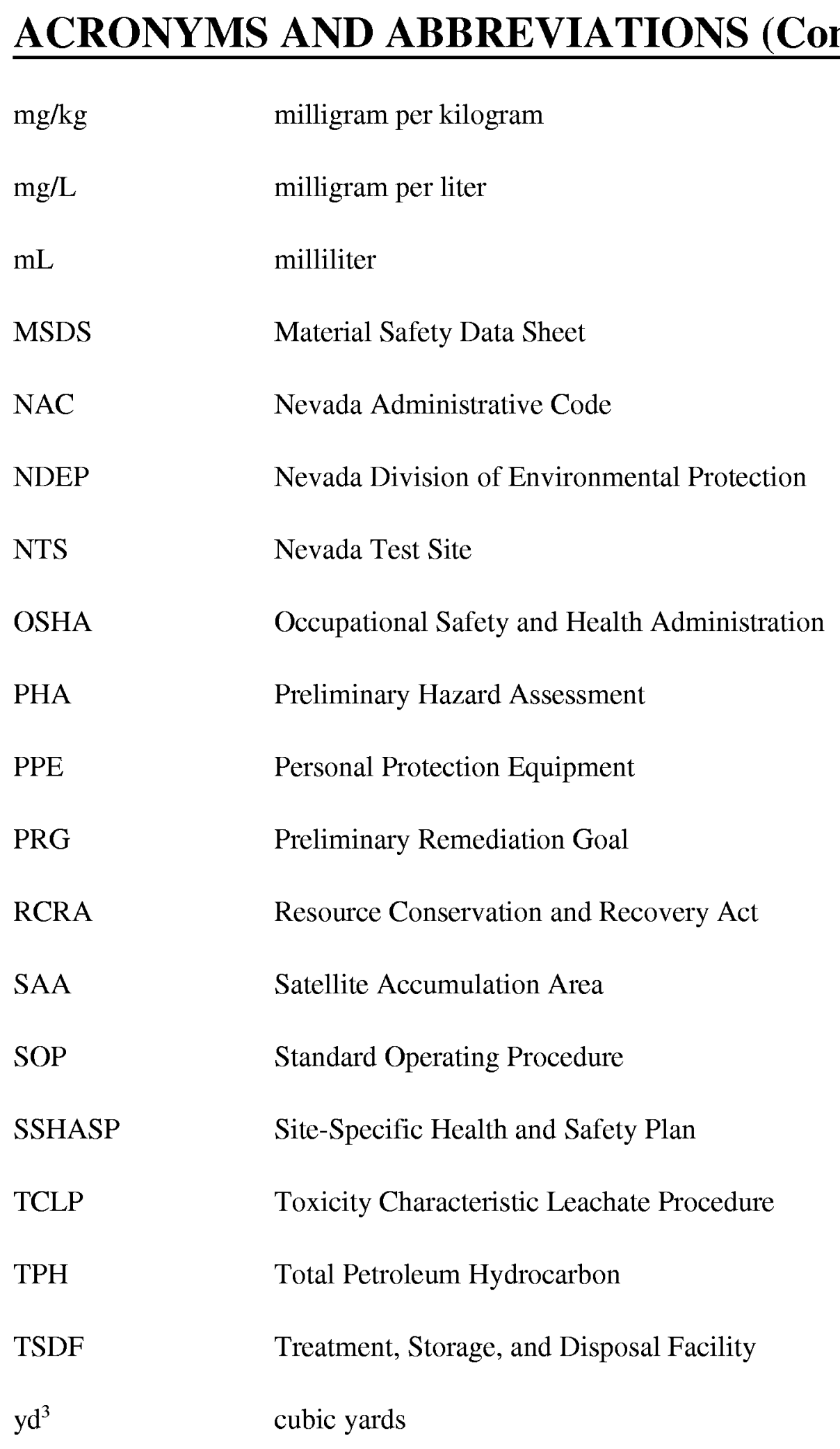


The Pesticide Release Site is identified in the Federal Facility Agreement and Consent Order (FFACO) as Corrective Action Unit (CAU) 340. The CAU is located in Areas 23 and 15 of the Nevada Test Site (NTS) and includes three Corrective Action Sites (CAS).

The Area 23 Quonset Hut 800 Pesticide Release Ditch (CAS 23-21-01) was used to steam-clean pesticide/herbicide applicators. The steam-cleaning rinsate drained to a solids/oil separator which overflowed to a drainage ditch that ran south from the quonset hut. Pesticide/herbicide rinsate was also discharged to the ditch from two sinks and a washer inside Quonset Hut 800. Although Quonset Hut 800 has been in existence since 1952, the time period for disposal or amount of pesticide/herbicide disposed is unknown.

The Area 23 Skid Huts Pesticide Storage (CAS 23-28-03) were used for storing, mixing, and disposing of excess pesticide/herbicide solutions and rinsate directly to the ground near the buildings. By 1983, all pesticides and herbicides at the NTS were consolidated at the Skid Huts and discharge directly to the ground was ceased.

The Area 15 Quonset Hut 15-11 Pesticide Storage (CAS 15-18-02) is located in Area 15 of the NTS. It was used to store farm supplies, light equipment, pesticides, herbicides, and fertilizers from the late 1960 s to the early 1980s. The only discharge of pesticides/herbicides at this quonset hut would have been from accidental spills or releases.

Based on the results of the Characterization Report, only pesticides and petroleum hydrocarbons were found in the areas around Quonset Hut 800 and the Skid Huts. The pesticides include 4,4'-DDD, 4,4'DDE, 4,4'-DDT, Chlordane, Aldrin, Dieldrin, Heptachlor, and Heptachlor Epoxide. Leachable Chlordane was detected at 0.121 milligrams per liter $(\mathrm{mg} / \mathrm{L})$ and $0.03 \mathrm{mg} / \mathrm{L}$ near the Skid Huts, which exceeds the U.S. Environmental Protection Agency's (EPA) toxicity characteristic for hazardous waste of $0.03 \mathrm{mg} / \mathrm{L}$ (EPA, 1996c). All other leachable concentrations of pesticides were either nondetect or below the toxicity characteristic. Petroleum hydrocarbons were detected at Quonset Hut 800 and the Skid Huts at levels up to 970 milligrams per kilogram $(\mathrm{mg} / \mathrm{kg})$, which is above the Nevada Division of Environmental Protection action level of $100 \mathrm{mg} / \mathrm{kg}$. The petroleum hydrocarbons were associated with elevated levels of pesticides and will be removed and disposed with them. No constituents of concern were found at Quonset Hut 15-11; therefore, no further action is warranted at this CAS.

Clean closure involves the excavation and disposal of impacted soil. Soil containing hazardous Chlordane will be managed and disposed as a Resource Conservation and Recovery Act hazardous waste. Soil containing petroleum hydrocarbon will be disposed in the Area 6 Hydrocarbon Landfill. All other soil will be disposed in the Area 23 Sanitary Landfill. Upon completion of excavation, soil samples will be collected from the excavated area to verify that the pesticides and petroleum hydrocarbons have been removed. The excavated area will then be backfilled and regraded. Postclosure care is not required because this is a clean closure. 
THIS PAGE INTENTIONALLY LEFT BLANK 


\subsection{INTRODUCTION}

The Pesticide Release Sites are located in Areas 15 and 23 of the Nevada Test Site (NTS) (Figure 1). The site is listed in the Federal Facility Agreement and Consent Order (FFACO, 1996) as Corrective Action Unit (CAU) 340 and includes the following Corrective Action Sites (CAS):

C 23-21-01- Area 23 Quonset Hut 800 Pesticide Release Ditch.

C 23-28-03- Area 23 Skid Huts Pesticide Storage.

C 15-18-02- Area 15 Quonset Hut 15-11 Pesticide Storage.

The site history for each CAS was provided in the Corrective Action Investigation Plan (CAIP) (U.S. Department of Energy [DOE], 1998a). Quonset Hut 800 was used to steam-clean pesticide/herbicide applicators. The steam-cleaning rinsate drained to a solids/oil separator which overflowed to a drainage ditch that ran south from the quonset hut (Figure 2). Pesticide/herbicide rinsate was also discharged to the ditch from two sinks and a washer inside Quonset Hut 800. Although Quonset Hut 800 has been in existence since 1952, the time period for disposal or amount of pesticide/herbicide disposed is unknown.

The Skid Huts were used for storing, mixing, and disposing of excess pesticide/herbicide solutions and rinsate directly to the ground near the buildings. By 1983, all pesticides and herbicides stored and managed at the NTS were consolidated at the Skid Huts. In 1983, the handling and disposal procedures for pesticides/herbicides were also changed so that any remnant solutions and rinsate were no longer discharged directly to the ground.

Quonset Hut 15-11 is located in Area 15 of the NTS. It was used to store farm supplies, light equipment, pesticides, herbicides, and fertilizers from the late 1960 s to the early $1980 \mathrm{~s}$. The only discharge of pesticides/herbicides at this quonset hut would have been from accidental spills or releases.

\subsection{PURPOSE}

The purpose of this Corrective Action Plan is to provide the strategy and methodology to close the Pesticide Release Site. The CAU will be closed following state and federal regulations and the FFACO (1996). Site characterization was performed in multiple phases at each CAS. Sampling activities were conducted during March and April 1998 at all three CAS. The first phase involved surface and near surface soil samples collected with hand tools. The second phase involved the collection of soil samples at Quonset Hut 800 and the Skid Huts from a depth of 0 to 1.2 meters (m) $(0$ to 4 feet [ft]) using a direct-push method. In September 1998, soil samples were collected between Quonset Hut 800 and the Skid Huts in the flood channel and 


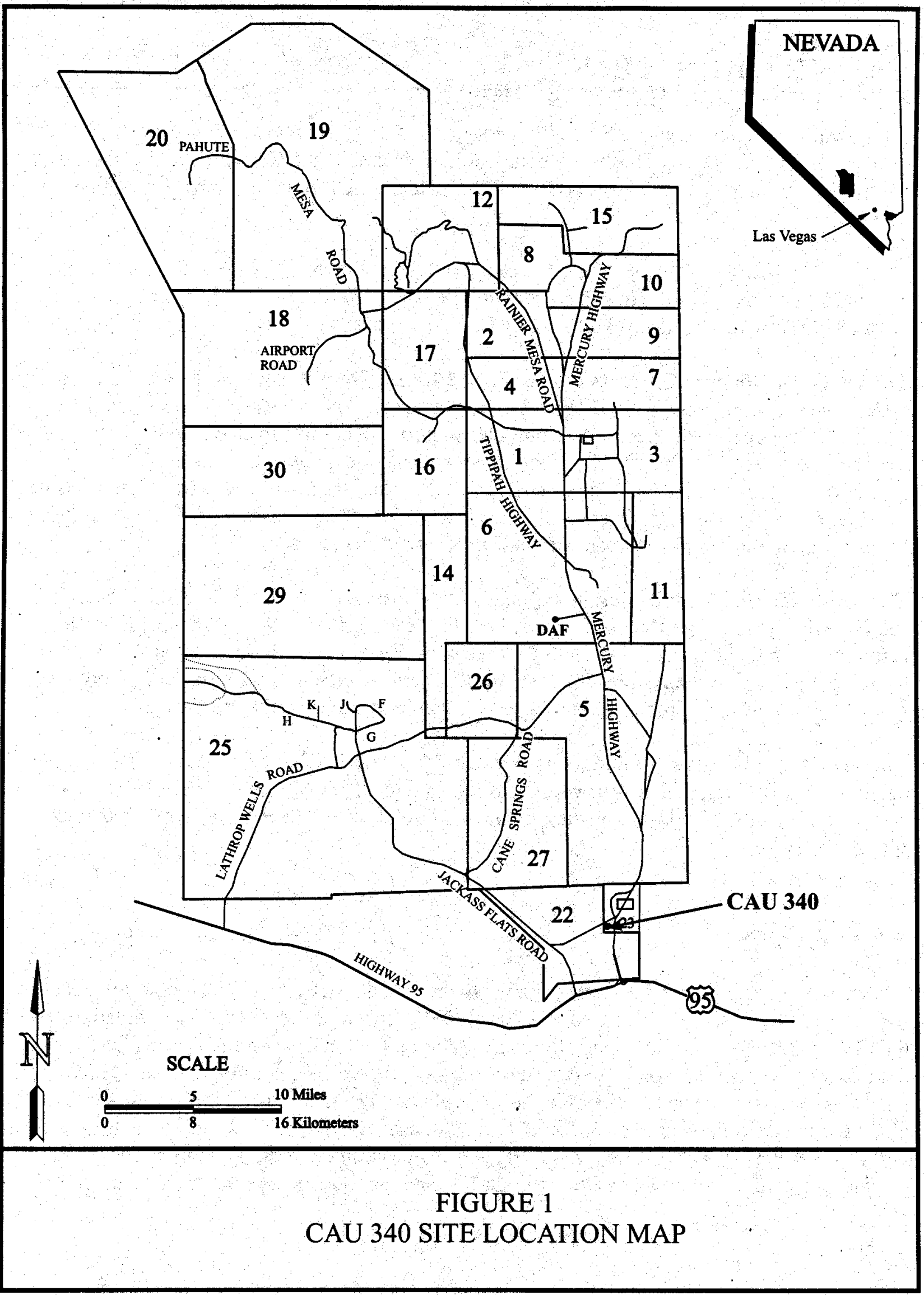




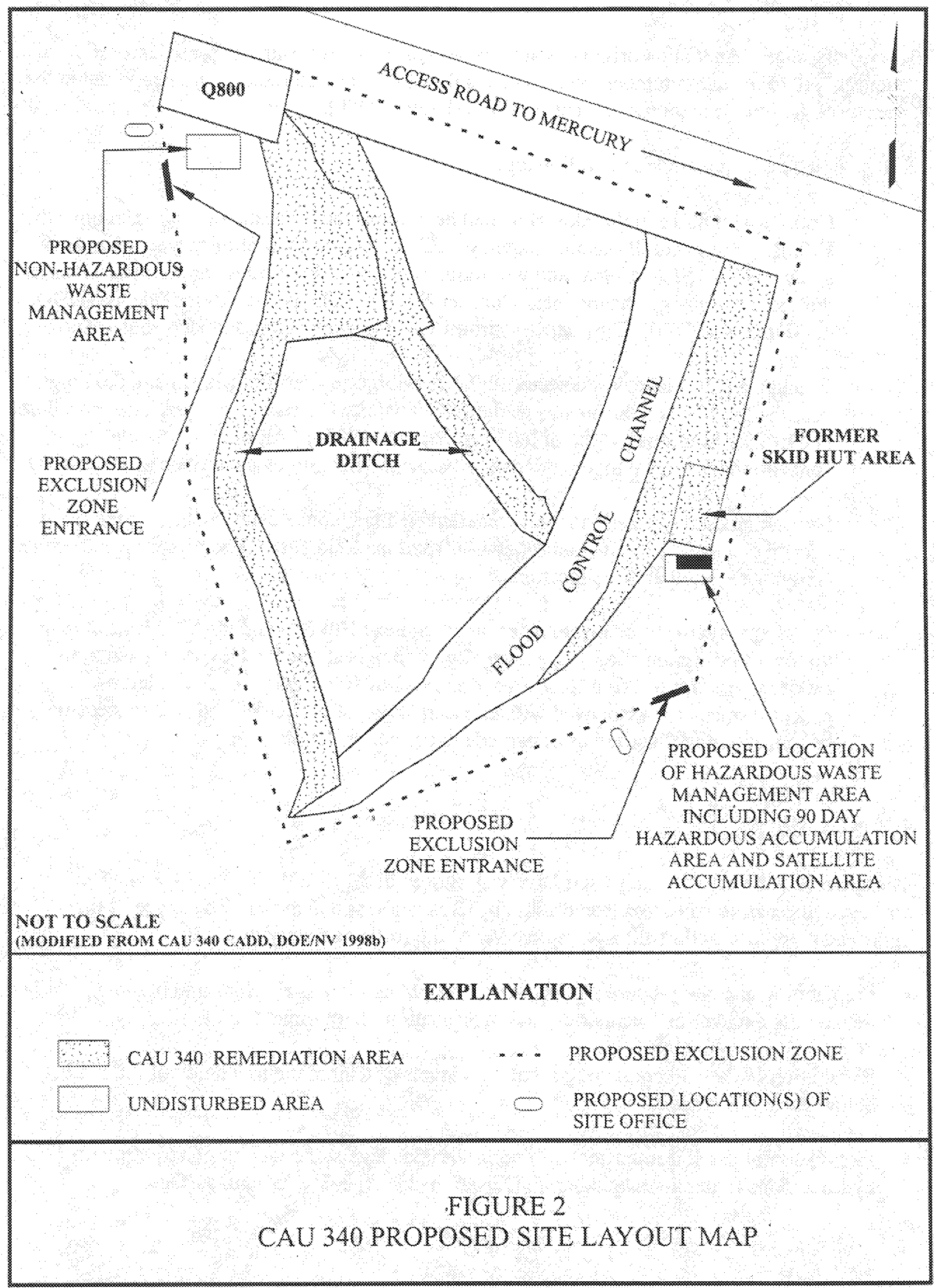


second drainage channel that originates at Quonset Hut 800. Soil samples were also collected at Quonset Hut 15-11 in September 1998. The results of the characterization were reported in the Corrective Action Decision Document (CADD) (DOE, 1998b).

Soil sample results concluded the following:

C Quonset Hut 800 and the Skid Huts had been impacted by pesticides that are above the U.S. Environmental Protection Agency's (EPA) Region IX preliminary remediation goals (PRGs) (EPA,1996a) and will require removal. Pesticides were also detected in the second drainage channel near Quonset Hut 800. The pesticides include 4,4'-DDD, 4,4'-DDE, 4,4'-DDT, Chlordane, Aldrin, Dieldrin, Heptachlor, and Heptachlor Epoxide.

C Leachable Chlordane was detected at 0.121 milligrams per liter $(\mathrm{mg} / \mathrm{L})$ and $0.03 \mathrm{mg} / \mathrm{L}$ near the Skid Huts, which exceeds the EPA Toxicity Characteristic Leachate Procedure (TCLP) for hazardous waste of $0.03 \mathrm{mg} / \mathrm{L}$ (EPA, 1996c). All other leachable concentrations were either nondetect or below the toxicity characteristic action levels.

C No pesticides above action levels were detected at Quonset Hut 15-11 or in the flood control channel between Quonset Hut 800 and the Skid Huts. Therefore, no corrective action is required at these locations.

C Petroleum hydrocarbons were detected at Quonset Hut 800 and the Skid Huts at levels up to 970 milligram per kilogram $(\mathrm{mg} / \mathrm{kg})$, which is above the Nevada Division of Environmental Protection (NDEP) action level of $100 \mathrm{mg} / \mathrm{kg}$. The petroleum hydrocarbons were associated with elevated levels of pesticides and will subsequently be removed and disposed of as part of the corrective action.

\subsection{SCOPE}

The approved corrective action alternative was chosen in the CADD (DOE, 1998b). The approved alternative includes clean closure by excavation and disposal. The scope of the approved corrective action alternative consists of the following activities:

C Preplanning and site preparation, including the preparation of all plans and permits, delineating excavation boundaries, and mobilization of equipment to the site.

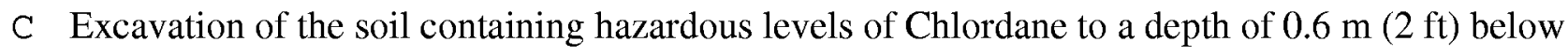
ground surface.

C Excavation of the soil impacted with nonhazardous levels of pesticides and petroleum hydrocarbons to depths ranging from 0.3-0.6 $\mathrm{m}(1-2 \mathrm{ft})$ below ground surface. 
C Closure verification sampling for pesticides will be completed using field screening and laboratory analysis. Pesticides will be removed to levels below the EPA Region IX Industrial Soils PRGs (EPA, 1996a). Petroleum hydrocarbons will be removed to below the NDEP Action Level of 100 $\mathrm{mg} / \mathrm{kg}$ (Nevada Administrative Code [NAC], 1996). Proposed remediation standards are provided in Table 1.

C Disposal of excavated materials following applicable federal, state, and DOE regulations in accordance with Section 2.3 of this Corrective Action Plan.

C Decontamination of equipment.

C Backfilling and grading of the site.

TABLE 1 - PROPOSED REMEDIATION STANDARDS FOR CAU 340

\begin{tabular}{||l|l|l|l||}
\hline Constituent & Region IX PRG $^{\mathbf{a}}$ & TCLP $^{\mathbf{b}}$ & NDEP Action Level \\
\hline \hline $4,4^{\prime}-$ DDD & $7.9 \mathrm{mg} / \mathrm{kg}$ & N/A & N/A \\
\hline $4,4^{\prime}-$ DDE & $5.6 \mathrm{mg} / \mathrm{kg}$ & N/A & N/A \\
\hline $4,4^{\prime}-$ DDT & $5.6 \mathrm{mg} / \mathrm{kg}$ & N/A & N/A \\
\hline Chlordane & $1.5 \mathrm{mg} / \mathrm{kg}$ & $0.03 \mathrm{mg} / \mathrm{L}$ & N/A \\
\hline Aldrin & $0.11 \mathrm{mg} / \mathrm{kg}$ & N/A & N/A \\
\hline Dieldrin & $0.12 \mathrm{mg} / \mathrm{kg}$ & N/A & N/A \\
\hline Heptachlor & $0.42 \mathrm{mg} / \mathrm{kg}$ & $0.008 \mathrm{mg} / \mathrm{L}$ & N/A \\
\hline Heptachlor Epoxide & $0.21 \mathrm{mg} / \mathrm{kg}$ & $0.008 \mathrm{mg} / \mathrm{L}$ & N/A \\
\hline Petroleum Hydrocarbons & N/A & N/A & $100 \mathrm{mg} / \mathrm{kg}$ \\
\hline \hline
\end{tabular}

a EPA Region IX PRGs (EPA, 1996a)

b EPA TCLP is to be used for hazardous waste designation only (EPA, 1996c)

c NDEP Action Level for petroleum hydrocarbons (NAC, 1996)

N/A Referenced standard is not applicable to the constituent. 


\subsection{CORRECTIVE ACTION PLAN CONTENTS}

This document is divided into the following sections in accordance with the approved FFACO Corrective Action Plan outline:

C Section 1.0 - Introduction

C Section 2.0 - Detailed Statement of Work

C Section 3.0 - Schedule

C Section 4.0 - Post-Closure Plan

C Section 5.0 - References

The appendices of this document have been modified from the approved FFACO outline. The following FFACO outline appendices have not been included or revised as indicated below:

C Appendix A1: Engineering Specifications and Drawings

This appendix is not warranted for the site as there are no construction or engineeredover requirements for closure.

C Appendix A2: Sampling and Analysis Plan

The sampling and analysis requirements for the site are detailed in Section 2.4 "Clean-up

Verification", therefore, a separate sampling and analysis plan is not included as an appendix.

C Appendix A3: Project Organization

This appendix is identified as Appendix C.

The appendices included in this document are provided as follows:

C Appendix A: Approval Documentation for Nonhazardous Waste Disposal

C Appendix B: Contingency Plan

C Appendix C: Project Organization 


\subsection{DETAILED STATEMENT OF WORK}

\subsection{APPROVED ALTERNATIVE IMPLEMENTATION}

This section describes how the approved alternative will be implemented at the Pesticide Release Site. The approved alternative includes clean closure with excavation and disposal of impacted soils, verification sampling, and regrading of the site. In addition to field activities, planning and site preparation are also required.

\subsubsection{Preplanning and Site Preparation}

Prior to beginning excavation activities, the following planning and preparation activities must be accomplished:

C Preparation of planning documents such as the Site-Specific Health and Safety Plan (SSHASP), and the Field Management Plan;

C Site preparation including utility clearance, work permits, and delineation of excavation boundaries;

C Identification and approval of a source for water for dust suppression and other construction activities;

C Scheduling and coordination of work with construction and waste management.

\subsubsection{Site-Specific Health and Safety Plan/Hazard Analysis}

A SSHASP Preliminary Hazard Assessment (PHA) and Hazard Assessment (HA) will be prepared. A copy of the document will be kept on file in the Bechtel Nevada (BN) Environmental Restoration and the BN Environmental, Safety, and Health Division offices in Mercury, Nevada. The original document will be kept by the Site Supervisor at the work site. The SSHASP, PHA, and HA will be available onsite for review and signature by all workers prior to beginning work at the site. The SSHASP will provide a detailed, job-specific plan covering protection against accidents and exposure of workers to contamination. It will also discuss weather/air monitoring, accident reporting, emergency procedures, and physical and environmental hazards. The work will also be performed following the U.S. Department of Energy, Nevada Operations Office (DOE/NV) Environmental Restoration Project Health and Safety Plan (DOE, 1998c) and the BN Environmental, Safety, and Health Manual (BN, 1999). In addition, the material safety data sheets (MSDS) file will be maintained by the Health and Safety Officer and will also be available on-site. 


\subsubsection{Field Management Plan}

A Field Management Plan will be prepared for the closure activities. The plan outlines how the work will be accomplished, an integrated safety management plan, and provides a detailed schedule for the project. In addition, it will identify the responsible parties for each aspect of the project and determine how decisions will be made. A copy of the Field Management Plan will be placed on file at the BN Environmental Restoration office in Mercury, Nevada, and a copy will also be available at the project field site.

\subsubsection{National Environmental Policy Act Documentation}

A National Environmental Policy Act checklist, and any subsequent documentation, will be completed prior to beginning any excavation activities at the site. If necessary, a follow-up survey will be performed and will report on the condition of existing trees, shrubs, grassed areas, cultural resources, sacred sites, and wildlife immediately adjacent to the area which may be affected by construction activities, equipment and material storage areas, and access routes. Based on the findings of this survey, the excavation activities at the Pesticide Release Site will follow all applicable federal, state, and local laws, regulations, and permits for protection of the environment.

\subsubsection{Field Activities}

\subsubsection{Excavation of the Soil Containing Hazardous Chlordane}

Approximately 4.5 to 7.5 cubic meters $\left(\mathrm{m}^{3}\right)$ ( 6 to 10 cubic yards $\left[\mathrm{yd}^{3}\right]$ ) of soil near the Skid Huts has been impacted with toxicity characteristic leachable Chlordane (Figure 3 ). This soil will be removed from an area approximately 9.3 square meters $\left(\mathrm{m}^{2}\right)\left(100\right.$ square feet $\left.\left[\mathrm{ft}^{2}\right]\right)$ and $0.6 \mathrm{~m}(2 \mathrm{ft})$ deep. The excavated soil will be placed in appropriate containers prior to being shipped to an off-site Resource Conservation and Recovery Act (RCRA) treatment, storage, and disposal facility. The waste will be managed following Section 2.3 of this Corrective Action Plan.

During excavation, the soil and excavated area will be examined visually for stains or discoloration that may be the result of the pesticides discharged in this area. In addition, field screening for pesticides will be conducted on the excavation floor and walls to determine if the impacted soil has been removed. Any areas identified as impacted above remediation levels will be removed.

Verification sampling will be done after all impacted soil is considered to have been removed. Sampling will be conducted in accordance with Section 2.4 of this Corrective Action Plan. Collected samples will be analyzed for total pesticides and total petroleum hydrocarbons, which are the only constituents of concern for this CAU. Samples analyzed for total pesticides will be analyzed for TCLP pesticides if preliminary analytical results indicate that leachable levels may 


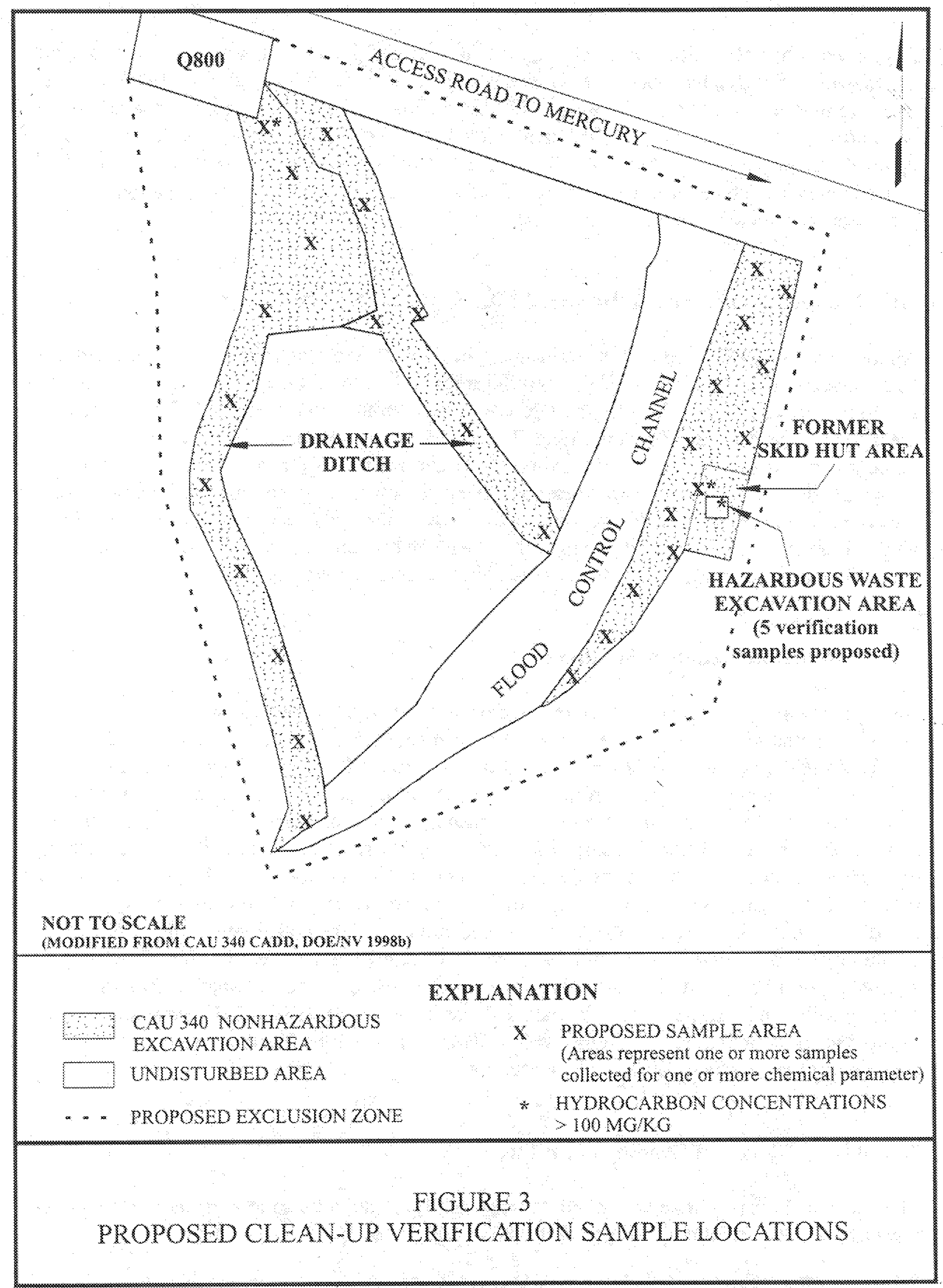


be present. The excavation will remain open until the results of verification samples show that remediation standards have been met and no additional excavation is required. Pesticides will be removed to levels below the EPA Region IX PRGs (EPA, 1996a). Petroleum hydrocarbons will be removed to levels below the NDEP action level of $100 \mathrm{mg} / \mathrm{kg}$ (NAC, 1996). Proposed clean-up levels are provided in Table 1. While the excavation is open, berms will be placed on the upgradient side of the excavation to direct runon and runoff away from the excavation if precipitation events are likely.

\subsubsection{Excavation of the Soil Impacted with Nonhazardous Pesticides}

Approximately $2,300 \mathrm{~m}^{3}\left(3,000 \mathrm{yd}^{3}\right)$ of soil impacted with nonhazardous levels of pesticides will be

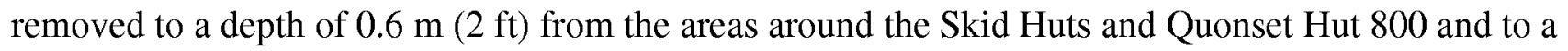

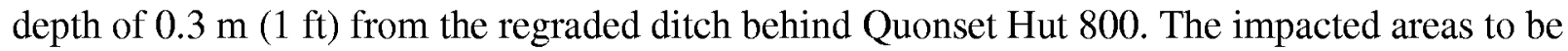
excavated are shown in Figure 3. Excavated soil will be placed into $15.3 \mathrm{~m}^{3}\left(20 \mathrm{yd}^{3}\right)$ end dump trucks or 208-liter (L) (55-gallon [gal]) drums for transfer to the Area 23 Sanitary Waste Landfill. In addition to nonhazardous levels of pesticides, petroleum hydrocarbons above the NDEP regulated level of 100 $\mathrm{mg} / \mathrm{kg}$ is also present in an area near Quonset Hut 800. This area will be excavated and transported to the Area 6 Hydrocarbon Landfill. Soil may be stockpiled, as warranted, if trucks are not readily available for loading.

\subsubsection{Decontamination of Equipment}

Any equipment that becomes contaminated during the excavation process will be decontaminated on-site. For larger pieces of equipment that cannot be decontaminated over a 208-L (55-gal) drum, a decontamination pad will be prepared by lining a bermed area large enough to hold a piece of heavy equipment. The equipment will be driven onto the pad and steam cleaned. Hand-held equipment will be cleaned with a solution of Alconox ${ }^{\mathrm{TM}}$ and water, and rinsed with clean water. Rinsate will be held in the bermed area and allowed to evaporate unless it is in excess of what the bermed area can hold. Excess rinsate will be pumped into drums. Any remaining rinsate at the time of final site housekeeping will be placed in containers and disposed of following Section 2.3 of this Closure Plan. The plastic liner will be placed in containers as compactable waste and disposed of in accordance with Section 2.3. Sampling equipment will be decontaminated using a one percent hydrochloric acid and isopropanol solution following DOE Standard Operating Procedure (SOP) ERD-05-701 "Sampling Equipment Decontamination" (DOE, 1998c). This rinsate will be placed in a satellite accumulation area located at Dorm B in Mercury.

\subsubsection{Backfilling and Grading of the Site}

The excavated areas will be backfilled with clean fill dirt and leveled to existing grade with the loader/backhoe to minimize surface obstructions and ponding. 


\subsection{CONSTRUCTION QUALITY ASSURANCE/QUALITY CONTROL}

Construction activities primarily consist of excavation and earth moving. Permeability and compaction testing will not be necessary. As a result, no construction quality assurance/quality control is required.

\subsection{WASTE MANAGEMENT}

Waste streams generated at CAU 340 will include soil containing nonhazardous pesticides, soil containing nonhazardous pesticides and petroleum hydrocarbons, nonhazardous sanitary trash, soil containing hazardous Chlordane and petroleum hydrocarbons, and hazardous waste liquid generated from decontamination activities, (one percent hydrochloric acid and isopropanol) and sampling activities (i.e field screening test kit standards).

Table 2 summarizes waste management practices that will be used during closure activities at CAU 340. Waste will be managed in accordance with state and federal regulations, DOE orders, and BN procedures. Nonhazardous waste types will be handled in accordance with DOE SOP ERD-05-210, "Management and Minimization of Nonhazardous Waste at the Nevada Test Site for the Nevada Environmental Restoration Project" (DOE/NV, 1994a). Hazardous waste will be handled in accordance with DOE SOP ERD-05-211, "Management and Minimization of Hazardous Waste and the Nevada Test Site for the Nevada Environmental Restoration Project” (DOE/NV, 1994b).

\subsubsection{NONHAZARDOUS WASTE}

Soils containing nonhazardous pesticides and soils containing nonhazardous pesticides and petroleum hydrocarbons will be placed into $15.3-\mathrm{m}^{3}\left(20-\mathrm{yd}^{3}\right)$ end dump trucks or 208-L (55-gal) drums and transported to the Area 23 Sanitary Waste Landfill or Area 6 Hydrocarbon Landfill, respectively. Soil may be stockpiled in impacted areas, as warranted, if trucks are not readily available for loading. Stockpiled soil will be covered at the end of the daily work shift with plastic and secured with sandbags. Nonhazardous waste will be placed in the Area 23 Sanitary Waste Landfill. Although the soil is not a regulated hazardous waste, the levels of pesticide present in the soil are a potential health hazard for the workers moving the soil. Therefore, to reduce the risk to workers at the Area 23 Landfill, the soil will be placed in the lanfill and covered to prevent disturbance of the soil by wind or future excavation activities at the landfill.

Approximately $2,600 \mathrm{~m}^{3}\left(3,000 \mathrm{yd}^{3}\right)$ of nonhazardous impacted soil will be generated. Petroleum hydrocarbon-impacted media and pesticide-impacted media are intermixed and will not be separated prior to disposal in the Area 6 Hydrocarbon Lanfill. Approval documentation for disposal of nonhazardous-impacted waste is provided in Appendix A. 


\section{TABLE 2 - MANAGEMENT OF WASTE TYPES TO BE PRODUCED AT THE PESTICIDE RELEASE SITE}

\begin{tabular}{|c|c|c|}
\hline MEDIA & WASTE TYPE & MANAGEMENT PRACTICE \\
\hline \multirow{3}{*}{ Impacted soil } & $\begin{array}{c}\text { Nonhazardous } \\
\text { pesticide-impacted soil }\end{array}$ & $\begin{array}{l}\text { Nonhazardous pesticide-impacted waste will be placed into } 208-\mathrm{L} \text { ( } 55 \text {-gal) drums or } 20 \text {-yd }{ }^{3} \text { end dumps. Soil } \\
\text { may be stockpiled, as warranted, if trucks are not readily available for loading. Stockpiled soil will be } \\
\text { located inside the exclusion zone and covered with plastic at the end of the day. The waste will be } \\
\text { disposed of at the Area } 23 \text { Sanitary Landfill and placed into a dedicated location. Nonhazardous waste will } \\
\text { be managed in accordance with DOE SOP ERD-05-210, "Management and Minimization of Nonhazardous } \\
\text { Waste at the Nevada Test Site for the Nevada Environmental Restoration Project" (DOE, 1994a). }\end{array}$ \\
\hline & $\begin{array}{l}\text { Nonhazardous pesticide } \\
\text { and petroleum } \\
\text { hydrocarbon impacted } \\
\text { soil }\end{array}$ & $\begin{array}{l}\text { Nonhazardous pesticide and petroleum hydrocarbon impacted waste will be placed into } 208 \text {-L ( } 55 \text {-gal) } \\
\text { drums or } 20-\text { yd }^{3} \text { end dumps. Soil may be stockpiled, as warranted, if trucks are not readily available for } \\
\text { loading. Stockpiled soil will be located inside the exclusion zone and covered with plastic at the end of the } \\
\text { day. The waste will be disposed of at the Area } 6 \text { Hydrocarbon Landfill. Nonhazardous waste will be } \\
\text { managed in accordance with DOE SOP ERD-05-210, "Management and Minimization of Nonhazardous } \\
\text { Waste at the Nevada Test Site for the Nevada Environmental Restoration Project" (DOE, 1994a). }\end{array}$ \\
\hline & $\begin{array}{c}\text { Hazardous Waste } \\
\text { (D020 chlordane, D031 } \\
\text { heptachlor) }\end{array}$ & $\begin{array}{l}\text { Waste will be placed directly into roll-offs or 208-L ( } 55 \text {-gal) drums located in a 90-day hazardous waste } \\
\text { accumulation area. Waste will be transported to an off-site treatment, storage, and disposal facility. All } \\
\text { hazardous waste will be managed in accordance with DOE SOP ERD-05-211, "Management and } \\
\text { Minimization of Hazardous Waste at the Nevada Test Site for the Nevada Environmental Restoration } \\
\text { Project" (DOE, 1994b). }\end{array}$ \\
\hline
\end{tabular}


TABLE 2 (Continued) - MANAGEMENT OF WASTE TYPES TO BE PRODUCED AT THE PESTICIDE RELEASE SITE

\begin{tabular}{|c|c|c|}
\hline MEDIA & WASIE TYPE & MANAGEMENT PRACTICE \\
\hline \multirow{3}{*}{$\begin{array}{l}\text { Decontamination } \\
\text { Rinsate and Plastic } \\
\text { Liner }\end{array}$} & $\begin{array}{l}\text { Nonhazardous } \\
\text { decontamination rinsate } \\
\text { and liner }\end{array}$ & $\begin{array}{l}\text { Decontamination rinsate from heavy equipment decontamination (Alconox and water) that remains in the } \\
\text { lined berm at the close of the project will be placed into a } 208 \mathrm{~L} \text { ( } 55 \text {-gal) drum prior to disposal in the Area } \\
23 \text { Sewage Lagoon. The decontamination liner along with other nonhazardous personal protection } \\
\text { equipment (PPE), will be disposed of in the Area } 23 \text { Sanitary Waste Landfill. Nonhazardous waste will be } \\
\text { managed in accordance with DOE SOP ERD-05-210, "Management and Minimization of Nonhazardous } \\
\text { Waste at the Nevada Test Site for the Nevada Environmental Restoration Project" (DOE, 1994a). }\end{array}$ \\
\hline & $\begin{array}{l}\text { Hazardous waste } \\
\text { decontamination rinsate }\end{array}$ & $\begin{array}{l}\text { Heavy equipment will be decontaminated with Alconox and water and the rinsate collected over the } \\
\text { hazardous waste soil pile or containerized soil. All hazardous waste will be managed in accordance with } \\
\text { DOE SOP ERD-05-211, "Management and Minimization of Hazardous Waste at the Nevada Test Site for } \\
\text { the Nevada Environmental Restoration Project" (DOE, 1994b). }\end{array}$ \\
\hline & $\begin{array}{l}\text { Sampling equipment } \\
\text { decontamination } \\
\text { rinsate }\end{array}$ & $\begin{array}{l}\text { Sampling equipment will be decontaminated in accordance with DOE SOP ERD-05-701, "Sampling } \\
\text { Equipment Decontamination" (DOE, 1998d). Rinsate generated from the use of chemicals (isopropanol and } \\
1 \% \text { hydrochloric acid) during sampling equipment decontamination activities will be placed into the } \\
\text { Satellite Accumulation Area (SAA) located between Dorms B and C at the NTS and managed in } \\
\text { accordance with BN CN-C-A12.048-01, "Management of Hazardous Waste Satellite Accumulation Areas; } \\
\text { NTS \& NLVF"(BN, 1998). }\end{array}$ \\
\hline $\begin{array}{l}\text { Field Screening } \\
\text { Standards }\end{array}$ & $\begin{array}{l}\text { Methanol and Chlordane } \\
\text { (less than approximately } \\
10 \mathrm{ml} / \text { use) standards }\end{array}$ & $\begin{array}{l}\text { Used chemicals will be placed into an SAA and managed in accordance with BN CN-C-A12.048-01, } \\
\text { "Management of Hazardous Waste Satellite Accumulation Areas; NTS \& NLVF" (BN, 1998). }\end{array}$ \\
\hline
\end{tabular}


TABLE 2 (Continued) - MANAGEMENT OF WASTE TYPES TO BE PRODUCED AT THE PESTICIDE RELEASE SITE

\begin{tabular}{||c|c|l||}
\hline \hline MEDIA & WASTE TYPE & \multicolumn{1}{|c|}{ MANAGEMENT PRACTICE } \\
\hline \hline \multirow{2}{*}{$\begin{array}{c}\text { PPE and } \\
\text { miscellaneous } \\
\text { trash and } \\
\text { construction } \\
\text { debris. }\end{array}$} & $\begin{array}{c}\text { Nonhazardous pesticide- } \\
\text { impacted PPE, trash, and } \\
\text { construction debris }\end{array}$ & $\begin{array}{l}\text { Nonhazardous pesticide-impacted PPE, trash, and construction debris will be consolidated and disposed of } \\
\text { in the Area 23 Sanitary Waste Landfill. Nonhazardous waste will be managed in accordance with DOE SOP } \\
\text { ERD-05-210, "Management and Minimization of Nonhazardous Waste at the Nevada Test Site for the } \\
\text { Nevada Environmental Restoration Project" (DOE, 1994a). }\end{array}$ \\
\cline { 2 - 4 } & $\begin{array}{c}\text { Nonhazardous PPE, trash, } \\
\text { and }\end{array}$ & $\begin{array}{l}\text { Nonhazardous PPE, trash, and construction debris will be disposed of in the Area 23 Sanitary Waste } \\
\text { Landfill. }\end{array}$ \\
\cline { 2 - 4 } & $\begin{array}{c}\text { Hazardous waste- } \\
\text { impacted PPE, trash, and } \\
\text { construction debris }\end{array}$ & $\begin{array}{l}\text { Hazardous waste-impacted PPE, trash, and construction debris will be consolidated and disposed of with } \\
\text { the hazardous waste soils. All hazardous waste will be managed in accordance with DOE SOP } \\
\text { ERD-05-211, "Management and Minimization of Hazardous Waste at the Nevada Test Site for the Nevada } \\
\text { Environmental Restoration Project" (DOE, 1994b). }\end{array}$ \\
\hline
\end{tabular}


Excess soil remaining on heavy equipment used in the removal of nonhazardous pesticide-impacted waste (such as the backhoe bucket and/or front end loader or other heavy equipment) will be removed through decontamination over the waste soil pile or a lined berm located inside of the CAU 340 exclusion zone. At the end of the project field activities, decontamination rinsate remaining in the lined berm will be removed and placed into a $208-\mathrm{L}(55-\mathrm{gal}) \mathrm{drum}$. The rinsate will be disposed of in the Area 23 Sewage Lagoons. Other nonhazardous waste, such as sanitary trash, PPE, the lined berm, and miscellaneous construction debris, will be disposed of in the Area 23 Sanitary Waste Landfill.

\subsubsection{HAZARDOUS WASTE}

Approximately $7.5 \mathrm{~m}^{3}\left(10 \mathrm{yd}^{3}\right)$ of hazardous waste soil (i.e., D020 chlordane, D031 heptachlor) will be generated during closure activities. The waste will be placed directly into roll-offs, or temporarily stored in a 90-day Hazardous Accumulation Area, prior to being transported to an off-site RCRA Treatment, Storage, and Disposal Facility (TSDF). Heavy equipment impacted with hazardous waste will be decontaminated with Alconox and water. Because the volume of decontamination rinsate is expected to be minimal, the water will be collected over the hazardous waste soil pile or containerized soil. Any PPE that may have contacted hazardous materials, will be combined with hazardous waste soil and sent to an off-site RCRA TSDF.

Hazardous waste liquids generated from field-screening test kits (i.e., chlordane and methanol standards) will be containerized and placed into an on-site SAA. Sampling equipment decontamination will not take place on-site. Instead, equipment will be decontaminated in accordance with DOE SOP ERD-05-701, Sampling Equipment Decontamination, near the Dorm B and C SAA. Rinsate from sampling equipment decontamination activities containing isopropanol and one percent hydrochloric acid will be placed into the SAA located near Dorms B and C of Area 23 at the NTS.

PPE and materials suspected of contacting hazardous materials will be combined with the hazardous waste soil and disposed of as hazardous waste. All hazardous wastes generated during closure activities will be transported off-site to an off-site TSDF.

\subsubsection{CONTAINER MANAGEMENT}

All containers will be handled following Title 40 Code of Federal Regulations (CFR) $\$ 262.34$ (EPA, 1996d) and Subpart I of Title 40 CFR $\$ 265$ (EPA, 1996f) which specifies the use and management of containers. All containers will be in good condition (no significant rust or dents) and will be filled to 7/8 of the maximum container's capacity. If a container begins to leak, the contents will be transferred to an appropriate container for the material to be stored, that is in good condition. The containers will be lined or made of a material that will not react with the waste. The containers will be closed while stored on-site, unless waste is added, removed, or examined. Drums will be handled in a manner that will not 
jeopardize the integrity of the container. Drum containers will be locked before the end of each work day.

Appropriate labels and relevant information will be marked on each container with an indelible marker, or equivalent. The information will be legible and clearly visible for inspections. Pertinent data may be written on duct tape or a blank adhesive label affixed to the side of the container. The containers will be labeled with information such as:

C Waste-tracking label, if applicable.

C Type of waste in the container.

C Location waste was derived from.

C Date of accumulation.

C Awaiting/pending analysis if sampling is required.

Roll offs used for the transportation of hazardous waste soil will be provided by an off-site contractor. Materials will be appropriately secured, placarded, and transported to an off-site RCRA TSDF in accordance with all applicable U.S. Department of Transportation regulations.

End dumps or other appropriate equipment will be used to transfer nonhazardous pesticide-impacted soils from CAU 340 to the Area 23 Sanitary Waste Landfill.

\subsubsection{SITE CONTROL}

Dust containing pesticides may be generated during field activities. Where appropriate, temporary fencing will be constructed around the exclusion zone and work areas. Warning signs will be posted. Only properly trained personnel wearing appropriate PPE will enter the exclusion zone. Waste management areas and lined decontamination berms will be located inside of the exclusion zone. The proposed waste management areas and proposed exclusion zone are shown in Figure 2.

\subsubsection{PREPAREDNESS AND PREVENTION}

Under Title 40 CFR $§ 265$, Subpart C (EPA, 1996f), all hazardous waste facilities must be maintained and operated in a manner that minimizes the possibility of fire, explosion, or any unplanned event. Hazards posed by wastes stored at CAU 340, and the containers in which they will be stored, do not require a specific kind of equipment; however fire extinguishers will be available on-site. Two-way radios (hand held and field vehicle) and MSDSs will be available. NTS Emergency Response Teams, the NTS Fire Department, and the Nye County Sheriff's office will be provided a site summary and map of the location prior to commencing field activities. They will also be notified when field activities begin and end. 
Mercury Medical will be informed of the type of injury or illness that could result from fires, explosions, or releases at the facility (i.e., inhalation of pesticide vapors). The nearest emergency support service is located in Building 650 of Area 23 and will be noted in the Site-Specific Health and Safety Plan (SSHASP) that will be read and signed by all workers prior to the start of field activities.

Aisle space between waste containers on-site will be sufficient to allow for unobstructed movement of personnel, fire protection equipment, spill control equipment, and decontamination equipment to any area of the facility in the event of an emergency.

\subsubsection{CONTINGENCY PLAN}

As required under Title 40 CFR $\S 265$, Subpart D (EPA, 1996f), a contingency plan will be designed to minimize hazards to human health and/or the environment in the event of fire, explosion, and/or any unplanned or non-sudden release of hazardous waste constituents. The provisions of the plan must be carried out immediately after such an event and provide actions that facility personnel will take.

A copy of the contingency plan, and all revisions, will be maintained at the facility and will also be provided to the NTS Fire Protection and Emergency Medical Services. There will be at least one emergency response employee on-call at all times. This person will have the authority to commit the resources needed to carry out the contingency plan. The emergency coordinator will have a thorough knowledge of all aspects of the contingency plan, all operations and activities at the facility, the location and characteristics of the waste handled, the location facility records, and the facility layout. A copy of the contingency plan is provided in Appendix B.

\subsubsection{PERSONNEL TRAINING}

Training is required for all personnel managing waste in a 90-day storage area (i.e., hazardous waste facility) as part of Title 40 CFR $\S 265$, Subpart B (EPA, 1996f). The program may be classroom instruction or on-the job training. On-the-job training must be designed so that personnel are able to respond effectively to emergencies by familiarizing themselves with emergency procedures, equipment, and systems. Training records are maintained at the Environmental Restoration office in Mercury, NV.

Title 29 CFR 1910.120 (EPA, 1996b) details the occupational safety and health requirements that will be followed for personnel supporting excavation activities. All personnel will be required to read, understand, and sign the SSHASP prior to working at the site. A tailgate safety briefing will be conducted every morning and, as needed, as activities or circumstances change. 


\subsubsection{INSPECTIONS}

An inspection of the areas in which hazardous waste containers are stored will be conducted weekly. The purpose is to identify leaking or deteriorating containers due to corrosion or other factors. Unusual circumstances will be reported immediately so that corrective measures can be taken. Completed inspection forms will be maintained in the project files.

\subsubsection{WASTE MINIMIZATION}

For the duration of the project, site workers will adhere to the BN Waste Minimization and Pollution Prevention Program. Care will be taken to segregate waste from non-waste materials, when possible, to avoid the generation of additional hazardous waste.

\subsection{CLEAN-UP VERIFICATION}

\subsubsection{Verification Sampling}

Verification sampling is required for a site closure. A verification program must support the field decision that any remaining constituents of concern are less than remediation standards and provide the regulator with confidence that sufficient samples have been collected to verify that the site has been remediated. For the Pesticide Release Site, the approved CADD (DOE, 1998b) indicated that leachable Chlordane is the only RCRA constituent of concern above remediation standards. All verification samples will be analyzed for total pesticides. If preliminary total pesticides results indicate that leachable levels of pesticides may be present, the samples will then be analyzed for TCLP pesticides for waste management purposes. In addition, samples will also be analyzed for total petroleum hydrocarbons in the areas where hydrocarbons were detected during site characterization. A summary of the type and number of samples to be collected and the analyses to be performed is provided in Table 3. A one-week analytical turnaround time will be requested for all samples.

The excavation for the leachable Chlordane is expected to be $9.3 \mathrm{~m}^{2}\left(100 \mathrm{ft}^{2}\right)$ and $0.6 \mathrm{~m}(2 \mathrm{ft})$ deep. One verification soil sample will be collected from each side wall and the bottom of the excavation, for a total of five verification samples. In addition, 29 samples for pesticide analysis and 2 samples for hydrocarbon analysis will be collected from the areas of nonhazardous pesticide-impacted soil. These samples will be biased towards the location of site characterization sample locations that contained detectable levels of pesticides. Proposed verification sample locations are shown in Figure 3. Because the excavations are not expected to be deeper than $0.6 \mathrm{~m}(2 \mathrm{ft})$, samples will be collected by hand using a stainless steel scoop and placed in the proper containers. If overexcavation is necessary and

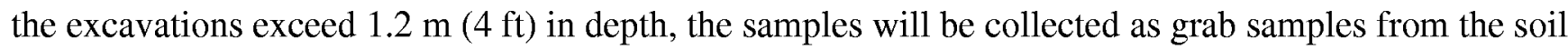
in a decontaminated bucket of the excavation equipment, and placed in the proper containers. 
TABLE 3- PESTICIDE RELEASE SITE VERIFICATION SAMPLING PARAMETERS

\begin{tabular}{|c|c|c|c|c|c|}
\hline PARAMETER & $\begin{array}{l}\text { NUMBER } \\
\text { OF } \\
\text { SAMPLES } \\
\end{array}$ & $\begin{array}{c}\text { NUMBER OF } \\
\text { QUALITY CONTROL } \\
\text { SAMPLES } \\
\end{array}$ & $\begin{array}{l}\text { SAMPLE } \\
\text { TOTAL }\end{array}$ & $\begin{array}{l}\text { ANALYTICAL } \\
\text { METHOD }\end{array}$ & $\begin{array}{c}\text { SAMPLE } \\
\text { CONTAINER }\end{array}$ \\
\hline \multicolumn{6}{|c|}{ Hazardous Soil Excavation Area } \\
\hline Total Pesticides & 5 & $\begin{array}{l}1 \text { Blind Replicate } \\
1 \text { Matrix Spike/Matrix } \\
\text { Spike Duplicate* }\end{array}$ & 6 & $\begin{array}{l}\text { SW846, EPA } \\
\text { Method } 8081\end{array}$ & $\begin{array}{l}1 \text { - 250-milliliter }(\mathrm{mL}) \\
\text { glass jar }\end{array}$ \\
\hline TCLP Pesticides & $5^{* *}$ & $\begin{array}{l}1 \text { Blind Replicate } \\
1 \text { Matrix Spike/Matrix } \\
\text { Spike Duplicate* }\end{array}$ & 6 & $\begin{array}{l}\text { SW846, EPA } \\
\text { Method 1311/8081 }\end{array}$ & $1-250-\mathrm{mL}$ glass jar \\
\hline $\begin{array}{l}\text { Total Petroleum } \\
\text { Hydrocarbon (TPH) Full } \\
\text { Scan } \\
\end{array}$ & 5 & $\begin{array}{l}1 \text { Blind Replicate } \\
1 \text { Matrix Spike/Matrix } \\
\text { Spike Duplicate* } \\
\end{array}$ & 6 & $\begin{array}{l}\text { SW846, EPA } \\
\text { Method 8015B } \\
\text { Modified } \\
\end{array}$ & $\begin{array}{l}1-250-\mathrm{mL} \text { glass jar- } \\
\text { zero headspace }\end{array}$ \\
\hline \multicolumn{6}{|c|}{ Nonhazardous Soil Excavation Area } \\
\hline Total Pesticides & 29 & $\begin{array}{c}2 \text { Blind Replicate } \\
1 \text { Matrix Spike/Matrix } \\
\text { Spike Duplicate* }\end{array}$ & 31 & $\begin{array}{l}\text { SW846, EPA } \\
\text { Method } 8081\end{array}$ & 1-250-mL glass jar \\
\hline TPH Full Scan & 2 & $\begin{array}{c}\text { 1Blind Replicate } \\
1 \text { Matrix Spike/Matrix } \\
\text { Snike Dunlicate* }\end{array}$ & 3 & $\begin{array}{l}\text { SW846, EPA } \\
\text { Method 8015B } \\
\text { Modified }\end{array}$ & $\begin{array}{l}1-250-\mathrm{mL} \text { glass jar- } \\
\text { zero headspace }\end{array}$ \\
\hline
\end{tabular}

* The matrix spike/matrix spike duplicate will not be a unique sample. One of the samples collected for analysis will be designated the matrix spike/matrix spike duplicate sample.

** TCLP pesticide samples will be collected; however, they will not be analyzed until preliminary total pesticide results have been evaluated. A one-week turnaround time will be requested on the total pesticide results to meet the 14-day hold time for TCLP pesticide analysis. 
All samples will be labeled with a unique sample number and handled under strict chain-of-custody procedures. Samples will be numbered using the following nomenclature:

\section{PESTSW-N2E}

Where:

C PEST is the site location.

C SW is a sidewall sample (BOT will be used for excavation floor samples).

$\mathrm{C} \quad \mathrm{N}$ is the compass direction of the sidewall (or relative position of excavation floor samples).

C $\quad 2$ is the depth of the sample measured in feet.

C E is the relative position of the sidewall sample if more than one sample is collected from the same depth but a different location on the same sidewall.

\subsubsection{Quality Control Samples}

One blind replicate will also be collected for every 20 samples collected. Each blind replicate will be labeled with its own distinct sample number so that the laboratory will not be able to readily identify it as a quality control sample. For every 20 samples collected, 1 sample will be designated for the laboratory to run a matrix spike and a matrix spike duplicate. At least one matrix spike and matrix spike duplicate will be from the hazardous excavation area and at least one will be from the nonhazardous excavation area. In addition, at least one equipment blank will be collected that represents the decontamination of sample equipment from the nonhazardous and hazardous excavation areas, respectively. The data packages provided by the laboratory will be validated and any laboratory method blanks will be evaluated by qualified personnel.

\subsection{PERMITS}

The only permit required for this project is an Excavation and Trenching Permit. An approved Excavating and Trenching Permit will be obtained prior to any excavation. The permit contains a justification for the trenching operation and a checklist of pertinent organizations who must inspect the site so that the trenching will not impact utilities. A copy of this permit will be kept at the project site by the site supervisor. 


\subsection{SCHEDULE}

\subsection{PROJECT SCHEDULE}

Because field activities are not anticipated to begin until Fiscal Year 2000, the final project schedule for the Pesticide Release Site Corrective Action has not been determined at this time. Therefore, the schedule provided here is tentative. The schedule will require modifications if conditions exist that are outside the assumptions on which the schedule is developed. The DOE will keep the NDEP appraised of any conditions that may impact the project schedule. In the event that the project schedule requires modifications, the DOE will consult with NDEP personnel prior to initiating any changes.

\subsection{FIELD WORK CLOSURE SCHEDULE}

A tentative schedule for planned field work consists of the following:

C Preparation for Field Work

C Excavation Activities

C Management and Disposal of Waste

C Securing the Site
October 1999

November-December 1999

November-December 1999

December 1999

Field work will be done in the safest and most efficient manner possible. Sufficient flexibility has been placed in the project schedule to account for minor difficulties (weather, equipment breakdown, etc.). The schedule may require modification if conditions exist that are outside the assumptions on which the schedule was developed. 


\subsection{POST-CLOSURE PLAN}

The clean closure of the Pesticide Release Site is expected to remove impacted soils to levels below proposed remediation standards and no post-closure care will be required.

\subsection{INSPECTIONS}

Because this is a clean closure, all constituents of concern will have been removed to the remediation standards. No inspections will be required following closure and the land can be released for unrestricted use.

\subsection{MONITORING}

Because this is a clean closure, post-closure monitoring is not required at the Pesticide Release Site as all constituents of concern will have been removed to the remediation standards. The land can be released for unrestricted use.

\subsection{MAINTENANCE AND REPAIR}

The site will be clean closed. Maintenance or repairs will not be necessary at the site following closure. 


\subsection{REFERENCES}

BN, see Bechtel Nevada

Bechtel Nevada, 1998, "Management of Hazardous Waste Satellite Accumulation Areas; NTS \& NLVF," Revision 1, BN CN-C-A12.048-01, Las Vegas, NV.

Bechtel Nevada, 1999, Environment, Safety, and Health Manual, Las Vegas, NV.

DOE, see U.S. Department of Energy.

EPA, see U.S. Environmental Protection Agency.

FFACO, 1996, Agreed to by the Nevada Division of Environmental Protection, the U.S. Department of Energy, and the U.S. Department of Defense.

NAC, see Nevada Administrative Code.

NDEP, see Nevada Division of Environmental Protection.

Nevada Administrative Code, 1996, NAC 445A, "Corrective Action," As adopted by the Nevada Environmental Commission, September, Carson City, NV.

U.S. Department of Energy, Nevada Operations Office, 1994a, Standard Operating Procedure ERD05-210, "Management and Minimization of Nonhazardous Waste at the Nevada Test Site for the Nevada Environmental Restoration Project," September 30, 1994, Las Vegas, NV.

U.S. Department of Energy, Nevada Operations Office, 1994b, Standard Operating Procedure ERD05-211, "Management and Minimization of Hazardous Waste at the Nevada Test Site for the Nevada Environmental Restoration Project," September 30, 1994, Las Vegas, NV.

U.S. Department of Energy, Nevada Operations Office, 1998a, Corrective Action Investigation Plan for CAU 340: Pesticide Release Site, Nevada Test Site, Nevada, DOE/NV--495, Las Vegas, NV. 
U.S. Department of Energy, Nevada Operations Office, 1998b, Corrective Action Decision Document for Corrective Action Unit 340: Pesticide Release Site. Nevada Test Site. Nevada, DOE/NV-525, Las Vegas, NV.

U.S. Department of Energy, Nevada Operations Office, 1998c, Nevada Environmental Restoration Project, Health and Safety Plan, Revision 3, Las Vegas, NV.

U.S. Department of Energy, Nevada Operations Office, 1998d, Sampling Equipment Decontamination. Revision 1, SOP ERD-05-701, Las Vegas, NV.

U.S. Environmental Protection Agency, 1996a, Region IX Preliminary Remediation Goals (PRGs), San Francisco, CA.

U.S. Environmental Protection Agency, 1996b, Title 29 Code of Federal Regulations 1910.120, "Hazardous Waste Operations and Emergency Response," Washington, D.C.

U.S. Environmental Protection Agency, 1996c, Title 40 Code of Federal Regulations 261.24, "Toxicity Characteristic," Washington, D.C.

U.S. Environmental Protection Agency, 1996d, Title 40 Code of Federal Regulations 262.34, "Accumulation Time," Washington, D.C.

U.S. Environmental Protection Agency, 1996e, Title 40 Code of Federal Regulations 264.228, 265.258, 264.280, "Closure and Post-Closure Care," Washington, D.C.

U.S. Environmental Protection Agency, 1996f, Title 40 Code of Federal Regulations 265, "Interim Status Standards for Owners and Operators of Hazardous Waste Treatment, Storage, and Disposal Facilities," Washington, D.C.

U.S. Environmental Protection Agency, 1996g, Title 40 Code of Federal Regulations 270.1, "EPA Administered Permit Programs: The Hazardous Waste Permit Program, Subpart A - General Information," Washington, D.C. 
APPENDIX A

APPROVAL DOCUMENTATION FOR NONHAZARDOUS WASTE DISPOSAL 


\section{THIS PAGE INTENTIONALLY LEFT BLANK}




\section{Bechtel Nevada}

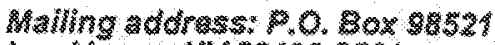

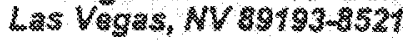

Express mall oniy: 2621 Losas Roze

North Las Vogas, WV 800304129.

$1300-\operatorname{LS}=99-0149$

March 17, 1999

E. Frank Di Sanza, Director

Waste Management Division

DOE Nevada Operations Office

P.O. Box 98518

Las Vegas, NV $89193-8518$

Subject: Contract No. DE-AC08-96NV11718

CEARACTERUZATION OF POTENTIAL WASTE

FROM CORRECTIVE A CTION UNTT (CAU) 340

PESTICDE RELEASE STTES

Project No. 04048

Bechtel Nevada (BN), Waste Management Program/Solid Waste Management (WMP/SWM), was asked by the DOE Nevada Operations Office (DOENV) to review the process knowledge and andytical data generated from the site characterization effort of Corrective Action Unì 340 and recommend a disposal method for the contaminated soil that may be generated during remediation efforts. In response to this request, WMP/SWM asked BN Environmental Compliance Department (ECD) to conduct an independent review and provide a disposal recommendation.

WMP/SWM requested all pertinent data from DOENV and Intemational Technologies Corporation (T). The following documentation was received and reviewed:

- Corrective Action Decision Document for Corrective Action Unit 340, Pesticide Release Sites, Nevada Test Site, Nevada (DOENV -525).

- CAU 340 Pesticide Release Sites History and Background Package (contains parts of the CAU project fle, including field notes, records of interviews with former and current employees, manifests, Material Safety Data Sheets, and previous sampling data).

- Laboratory data referenced in the Corrective Action Decision Document.

WMP/SWM and ECD reached the same conclusion on the characterization and disposal method for potential waste generation at CAU 340. The soll, which exceeds the Preliminary Action Levels (PALs) but does not exceed the Toxity Characteristic Leaching Procedure (TCLP) limit for pesticides and herbicides, will be classiffed as a nonhazardous waste. The soil in the small area by the skid huts, which has contamination of chlordane greater then the TCLP limit, will be classified as a hazardous waste. 
1300-LS-99-0149

E. F. Di Sanza

Page 2 of 2

March 17, 1999

Both ECD and WMP/SWM believe a good faith effort was conducted to determine process knowledge. This good fath eftort did not yield positive proof that restricted use pesticides and herbicides were used as a sole active ingredient. There is no conclusive evidence that indicates either rinsate from a "P" listed material or an unused materal of a sole active ingredient was discharged to the ground. Therefore, the waste camnot be considered "a listed hazardous waste."

The nonhazardous waste can be taken to either the Area 23 or $10 \mathrm{c}$ Landfll for disposal. The hazardous waste must be disposed at an off-site transportation, storage, and disposal faclity.

If you have any questions, please contact C. Stowell at $295-6904$.<smiles>CCC(C)OCCOCCO</smiles>

L. S. Sygitowicz, Manager

Waste Management Program

CAS:cjs

Subject Code: WMT3

ce:

Correspondence Control, NLVoos

J. L. Appenzeller-Wing, DOENV, 505

R. F. Boehlecke, T, 439

R. A Bull $1 T_{3}, 439$

J. T. Carill, DOENV, 505

D. X. Cowser, BN, NLVO 2

1. A Dickinson, BN, NLV080

C. L. Dutro, IT, 439

R. H. Guymon, BN, NTS327

A. M. Heidema, BN, NLV102

S. J. Nacht, BN, NTS306

P. M. Radack, BN, NTS327

C. J. Schwartze, BN, NTS207

I. L. Smith, BN, NTS306

C. A. Stowell, BN, NTS207

D. A. Watson, BN, NLV022 
APPENDIX B

\section{CONTINGENCY PLAN}




\section{THIS PAGE INTENTIONALLY LEFT BLANK}




\title{
AREA 23 \\ PESTICIDE RELEASE SITE CONTINGENCY PLAN AND EMERGENCY PROCEDURES
}

September 1999

\author{
Prepared for \\ U. S. Department of Energy \\ Nevada Operations Office \\ Environmental Restoration Division
}




\section{THIS PAGE INTENTIONALLY LEFT BLANK}


CAP.CAUNB. 340

Pesticide Release Site

Section: APPESADX B

Kewarion: 0

Date: $9 / 1 \% 9$

APPROVALS

Approved By:

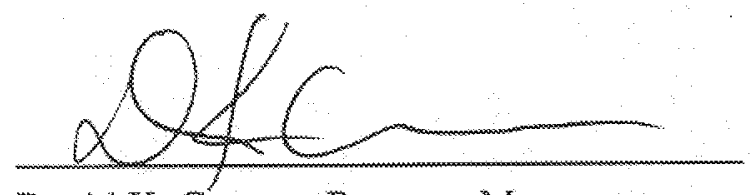

David K. Cower, Program Manager Environmental Restoration

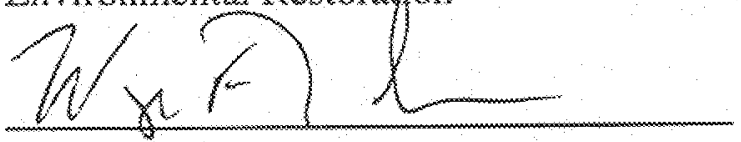

Wayne F. Johnson, Project Manager

Enviremental Restoration

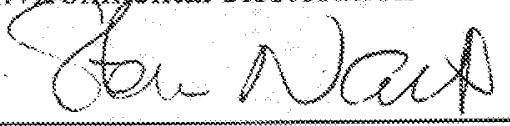

Steve J. Nacho, Operations Manager

Environmental Restoration

Concurred By:

$435 n^{5}$ Lethe

K. B. Mcolothlin, Manager

NTS Fire Protection and Emergency Medical Services

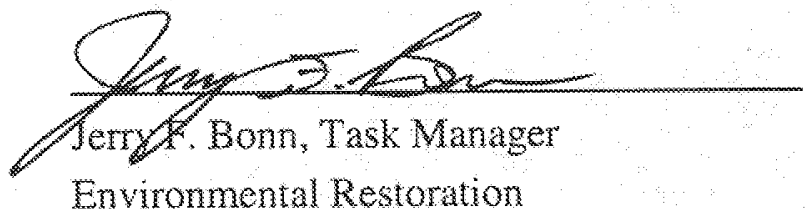

Prepared By:

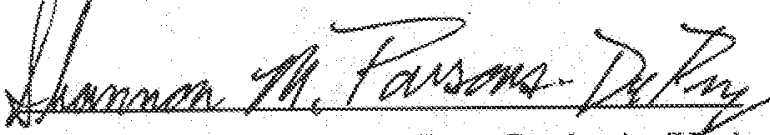

Shannon M. Parsons-DePry, Geologisu/Yydrogeologist

Environmental Restoration $\frac{9-9-94}{\text { Date }}$
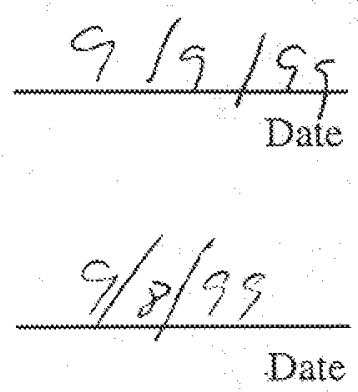

$$
9 / 8 / 99
$$

Date

9.8 .99

Date

918199

Date 


\section{THIS PAGE INTENTIONALLY LEFT BLANK}


ACRONYMS AND ABBREVIATIONS $\ldots \ldots \ldots \ldots \ldots \ldots \ldots \ldots \ldots \ldots \ldots \ldots \ldots$

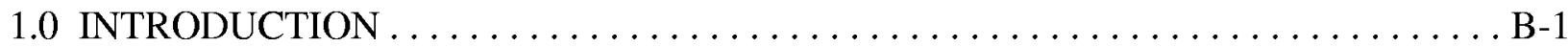

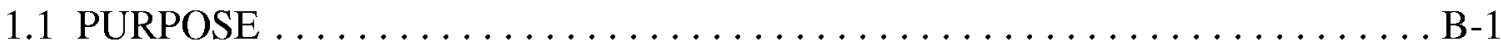

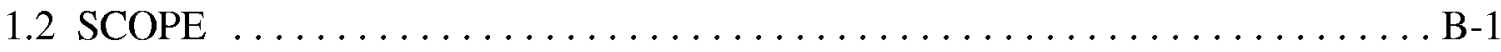

1.3 FACILITY DESCRIPTION $\ldots \ldots \ldots \ldots \ldots \ldots \ldots \ldots \ldots \ldots \ldots \ldots \ldots \ldots \ldots \ldots$

1.3.1 Site Location $\ldots \ldots \ldots \ldots \ldots \ldots \ldots \ldots \ldots \ldots \ldots \ldots \ldots \ldots \ldots \ldots \ldots$

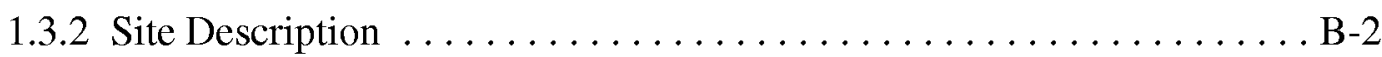

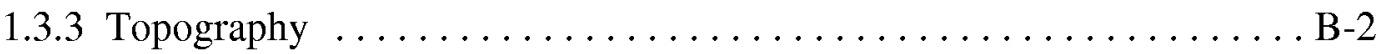

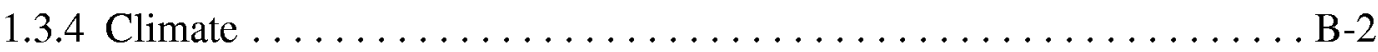

2.0 WASTE DESCRIPTIONS AND ASSOCIATED HAZARDS $\ldots \ldots \ldots \ldots \ldots \ldots$. $\ldots$

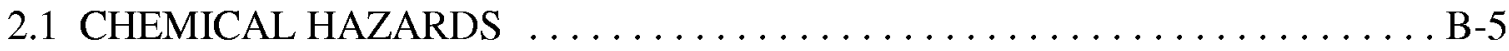

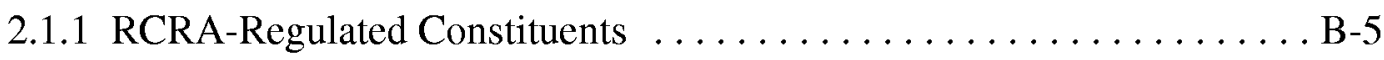

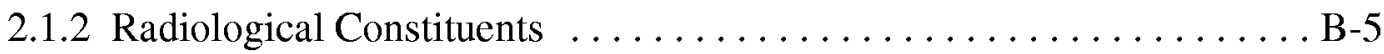

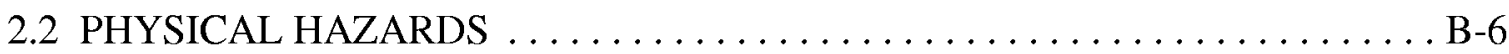

2.2.1 RCRA-Regulated Constituents $\ldots \ldots \ldots \ldots \ldots \ldots \ldots \ldots \ldots \ldots \ldots \ldots \ldots \ldots \ldots \ldots$ B-6

2.2.2 Radiological Constituents . . . . . . . . . . . . . . . B-6

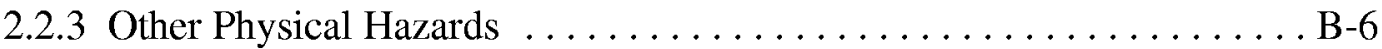

3.0 EMERGENCY NOTIFICATION PROCEDURES $\ldots \ldots \ldots \ldots \ldots \ldots \ldots \ldots \ldots \ldots$ B-7

3.1 DESIGNATION OF EMERGENCY COORDINATOR $\ldots \ldots \ldots \ldots \ldots \ldots \ldots$. . . .

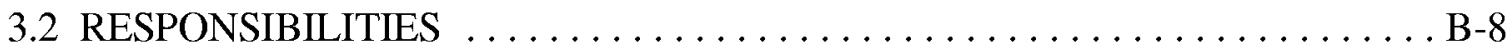

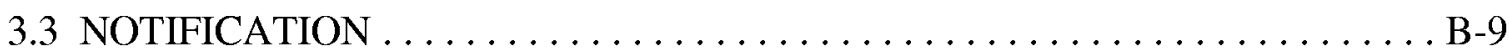

3.4 RESPONSE PROCEDURES $\ldots \ldots \ldots \ldots \ldots \ldots \ldots \ldots \ldots \ldots \ldots \ldots \ldots$

3.5 EVACUATION PLAN . . . . . . . . . . . . . . . . . . . B-10

3.6 EMERGENCY DECONTAMINATION AND FIRST AID $\ldots \ldots \ldots \ldots \ldots \ldots$. . . . .

3.7 CLEAN-UP . . . . . . . . . . . . . . . . . . . . . .

4.0 EMERGENCY SERVICES $\ldots \ldots \ldots \ldots \ldots \ldots \ldots \ldots \ldots \ldots \ldots \ldots \ldots \ldots \ldots \ldots \ldots \ldots \ldots \ldots$

4.1 ON-SITE CONDITION OF EMERGENCY SERVICES $\ldots \ldots \ldots \ldots \ldots \ldots . . . . . .13$

4.2 MEDICAL SERVICES . . . . . . . . . . . . . . . . . . B-13

4.3 FIRE PROTECTION AND EMERGENCY MEDICAL SERVICES . . . . . . B-13

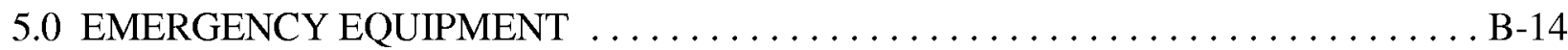

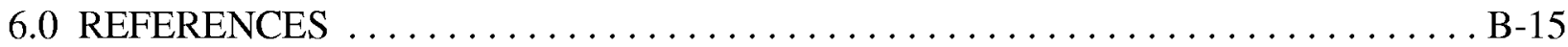




\section{TABLE OF CONTENTS (Continued)}

\section{FIGURES}

Figure 1 - CAU 340 Site Location Map . . . . . . . . . . . . . . . . . . B-3

Figure 2 - Emergency/Contingency Plan Notice That Will Be Posted at the Site . . . . . . . . B-4

Figure 3 - Injury/Illness/Accident Report $\ldots \ldots \ldots \ldots \ldots \ldots \ldots \ldots \ldots \ldots$. . . . . . . .

\section{TABLES}

Table 1 - List of Available Equipment and Location . . . . . . . . . . . . . . B-14 


\section{ACRONYMS AND ABBREVIATIONS}

$\begin{array}{ll}\text { BN } & \text { Bechtel Nevada } \\ \text { BNOM } & \text { Bechtel Nevada Occupational Medicine } \\ \text { CAS } & \text { Corrective Action Site } \\ \text { CFR } & \text { Code of Federal Regulations } \\ \text { CIC } & \text { Communication Information Center } \\ \text { EC } & \text { Emergency Coordinator } \\ \text { EPA } & \text { Environmental Protection Agency } \\ \text { ER } & \text { Environmental Restoration } \\ \text { PRE/L } & \text { Preliminary Remediation Goals } \\ \text { NTS } & \text { Nevada Test Site } \\ & \\ \text { PRA } & \text { Personal Protective Equipment } \\ & \end{array}$

B-V 
THIS PAGE INTENTIONALLY LEFT BLANK

B-vi 


\subsection{INTRODUCTION}

\subsection{PURPOSE}

This document satisfies the requirements for a contingency plan and emergency procedures required by the federal hazardous waste regulations defined in the Resource Conservation and Recovery Act (RCRA). These requirements are prescribed by:

- $\quad$ Title 40 Code of Federal Regulations (CFR) Part 265, Subparts C and D.

- $\quad$ Title 40 CFR 262.34.

- $\quad$ Title 29 CFR 1910.120, "Hazardous Waste Operations and Emergency Response.”

- $\quad$ BN Emergency Management Plan.

This plan discusses the actions that the BN Environmental Restoration (ER) and other Nevada Test Site (NTS) personnel will take in response to fires, explosions, or unplanned sudden or non-sudden releases of hazardous waste or hazardous waste constituents to the air, soil, or surface water at the Pesticide Release Site during closure activities.

\subsection{SCOPE}

This Plan covers a variety of emergencies at the Pesticide Release Site. This document applies to all personnel assigned to the Pesticide Release Site project activities.

\subsection{FACILITY DESCRIPTION}

\subsubsection{Site Location}

The Pesticide Release Site is an historic land disposal unit located in Area 23 of the NTS. Clean-up activities are required at the Area 23 Quonset Hut 800 Pesticide Release Ditch (Q800), the adjacent 
Area 23 Skid Huts Pesticide Storage (Corrective Action Site [CAS] 23-28-03), and the area between the two sites.

\subsubsection{Site Description}

The Area 23 Quonset Hut 800 Pesticide Release Ditch (CAS 23-21-01) was used to steam-clean pesticide/herbicide applicators. The steam-cleaning rinsate drained to a solids/oil separator which overflowed to a drainage ditch that ran south from the quonset hut. Pesticide/herbicide rinsate was also discharged to the ditch from two sinks and a washer inside Quonset Hut 800. Although Quonset Hut 800 has been in existence since 1952, the time period for disposal or amount of pesticide/herbicide disposed is unknown.

The Area 23 Skid Huts Pesticide Storage (CAS 23-28-03) were used for storing, mixing, and disposing of excess pesticide/herbicide solutions and rinsate directly to the ground near the buildings. By 1983, all pesticides and herbicides at the NTS were consolidated at the Skid Huts and discharge directly to the ground was ceased.

\subsubsection{Topography}

The NTS is located in the Great Basin of the Basin and Range province. The Pesticide Release Site is located in Area 23 of the NTS, near the Mercury Base Camp. The topography and soils in Mercury are typical of the NTS alluvial basins. The soil is dense, silty sand which contains gravel and scattered boulders and common layers of caliche. The alluvial plain at Mercury slopes gently to the southwest. The soil is dense, silty sand which contains gravel and scattered boulders and common layers of caliche. Mercury is located within a major drainage basin. A steeply sloping local sub-basin drains from the northeast directly into Mercury. The sub-basin is drained by an arroyo system and is subject to high peak runoff.

\subsubsection{Climate}

Lower elevations of the NTS receive approximately 15 centimeter (6 inches) of precipitation annually. Annual wind patterns are characterized by strong winds in the spring. The daily cycle is generally light winds at night, increasing winds from morning to afternoon and declining wind speed in the evening. Average monthly wind speed vary from 4 meter per second (13 feet per second) in April to 2.7 meter per second ( 9 feet per second) in November (Desert Research Institute, 1986). 
CAP.CAU NO 340

Festide Release Site

Section: APPEESDX

Kevsion: 0

Date: 91199

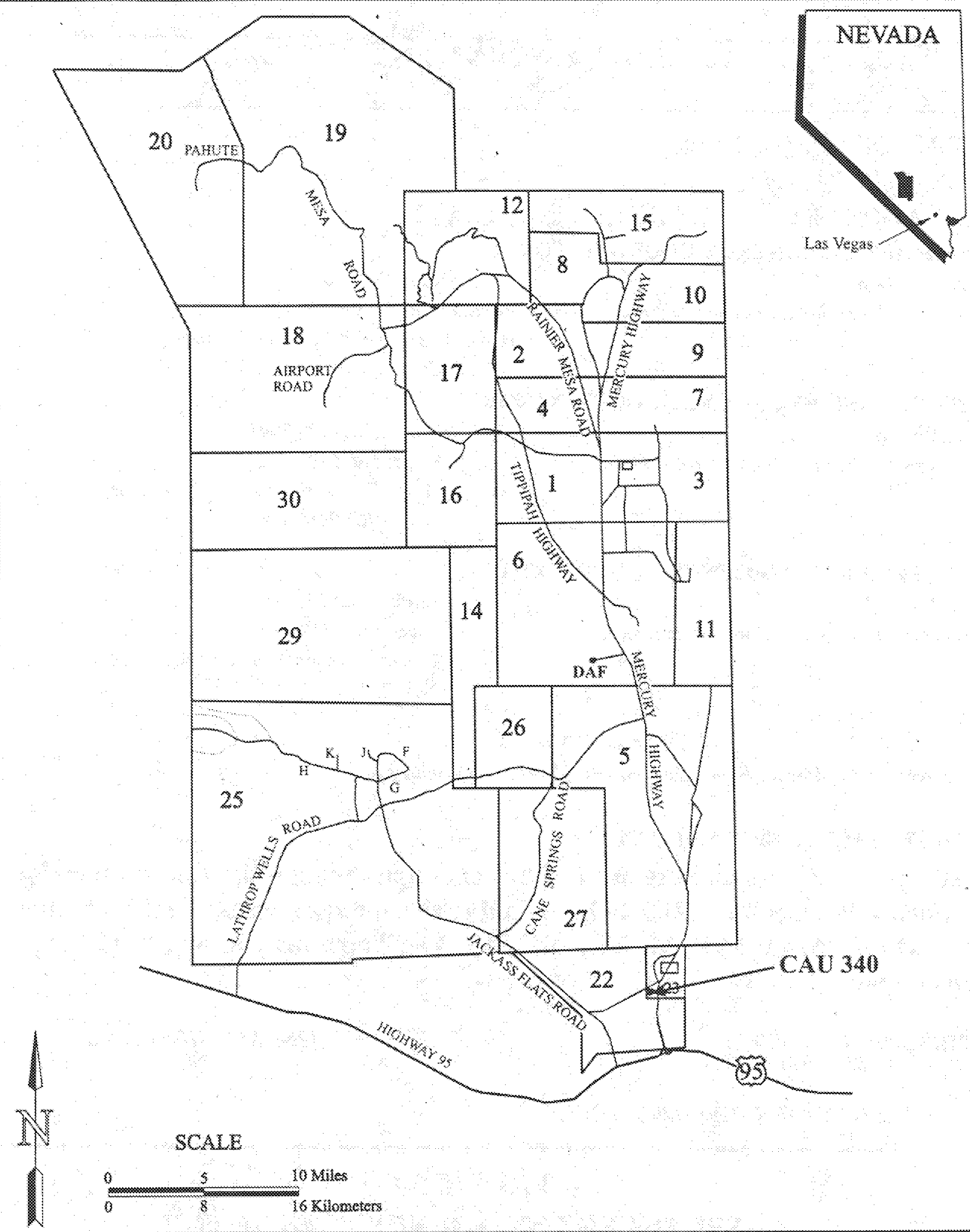

FIOURE 1

CAU 340 SITE LOCATION MAP 


\section{EMERGENCY/CONTINGENCY PLAN}

COMPANY: Bechtel Nevada

ADDRESS: Mercury, Nevada

LOCATION OF FACILITY: Nevada Test Site, Area 23

PRIMARY EMERGENCY COORDINATOR

Steve J. Nacht

Address: To be provided in field document
Work: (702) 295-1632

Pager: (702) 794-5692

Home: To be provided in field document

Net 3 \#762

\section{SECONDARY EMERGENCY COORDINATOR}

Jerry F. Bonn

Address: To be provided in field document
Work: (702) 295-7341

Pager: (702) 794-6325

Home: To be provided in field document

Net 3 \#763; Net 15 \#813

\section{ALTERNATE EMERGENCY COORDINATOR}

Curtis Obi

Address: To be provided in field document
Work: (702) 295- 5577

Pager: (702) 794-6659

Home: To be provided in field document

Net 15: 820

\section{DESCRIPTION OF WASTE HANDLED}

Pesticides and hydrocarbons contained in soil and decontamination water.

\section{EMERGENCY RESPONSE CONTACTS}

All emergency response teams can be contacted through the Communication Information Center (CIC) 24 hours a day seven days a week: CIC is reached by calling "MAYDAY, MAYDAY, MAYDAY" on a net radio or "911" by telephone

PRIMARY HOSPITAL:

Area 23, Building $650 \quad$ 295-1702

EMERGENCY MANAGEMENT OFFICE:

Area 23 295-1962
SECONDARY HOSPITAL:

N/A

FIGURE 2

EMERGENCY/CONTINGENCY PLAN NOTICE

TO BE POSTED AT THE SITE 


\subsection{WASTE DESCRIPTIONS AND ASSOCIATED HAZARDS}

The Pesticide Release Site contains materials that present chemical and physical hazards. Potential routes of entry could include inhalation, ingestion, absorption, and injection. The specific hazards associated with the site are described in the following sections.

\subsection{CHEMICAL HAZARDS}

The following is a generalization of the hazards associated with the various chemical classes that may possibly be encountered at the Pesticide Release Site.

\subsubsection{Resource Conservation and Recovery Act-Regulated Constituents}

The small area at the Skid Huts contains RCRA-regulated hazardous constituents. Leachable Chlordane was detected at 0.121 milligrams per liter $(\mathrm{mg} / \mathrm{L})$ and $0.03 \mathrm{mg} / \mathrm{L}$ near the Skid Huts (Department of Energy, 1998), which exceeds the Environmental Protection Agency's (EPA) toxicity characteristic for hazardous waste of $0.03 \mathrm{mg} / \mathrm{L}$ (EPA, 1996a). Chlordane is a known carcinogen. Acute exposure may cause blurred vision, confusion, ataxia, delirium, coughing, abdominal pain, nausea, vomiting, diarrhea, and irritation. Chronic exposure can cause tremors, convulsions, anuria, and potentially lung, liver, and kidney damage.

Other pesticides were detected at the site at levels below the RCRA toxicity hazard levels but above the EPA Region IX Preliminary Remediation Goals (PRGs) (EPA, 1996b). These pesticides include aldrin, dieldrin, heptachlor, and organochlorine pesticides and are also considered carcinogenic. Symptoms of exposure of similar to those for chlordane with acute exposure effecting the neurological systems and chronic exposure causing convulsions, coma, tremors, and potentially lung, liver, and kidney damage.

\subsubsection{Radiological Constituents}

No radiological constituents have been identified at this site. 


\subsection{PHYSICAL HAZARDS}

The following is a generalization of the physical hazards associated with the various chemical classes that may possibly be encountered at the Pesticide Release Site.

\subsubsection{RCRA-Regulated Constituents}

The RCRA-Regulated constituents themselves do not present any kind of physical hazard. All physical hazards will be associated with the removal and containerizing of the waste soil.

\subsubsection{Radiological Constituents}

No radiological constituents were identified at the site.

\subsubsection{Other Physical Hazards}

Other physical hazards present at the Pesticide Release Site are associated with container-handling, heavy equipment operations, working on uneven terrain, and working outdoors. These may include potential back injury, vehicle accidents, slip, trip, and fall accidents, heat and cold stress. Physical hazards are discussed in BN Safety Procedures and the Site-Specific Health and Safety Plan (SSHASP). 


\subsection{EMERGENCY NOTIFICATION PROCEDURES}

The reporting and notification procedure outlined in Bechtel Nevada (BN) Safety Procedure M-A11007, “Accidents/Incident Notifying, Investigating, and Reporting" (BN, 1996) will be followed in the event of an accident, injury or other incident. Expedient reporting and notification will be made for, but not limited to, personnel injury or fatality, toxic material release, fire, or explosion. Figure 2 shows the Emergency/Contingency Plan notice that will be posted at the site. Information includes a list of the telephone numbers, emergency response procedures, waste description, etc.

\subsection{DESIGNATION OF EMERGENCY COORDINATOR}

The Emergency Coordinator (EC) system consists of one primary EC, one secondary EC, and one alternate EC. The ECs are onsite or on call at all times. In the event of an emergency, the primary EC should be contacted; if not available, the secondary EC should be contacted. If neither of these are available, the alternate should be contacted. The individual who is available first becomes the EC for the situation. Actual home addresses and phone numbers for ECs will be provided in the document used in the field. The ECs appointed by the Environmental Restoration Program Manager are as follows:

\section{Primary Emergency Coordinator}

Steve J. Nacht

Address: To be provided in field document
Work: (702) 295-7234

Pager: (702) 794-5692

Home: To be provided in field document

Net 3 \#762

\section{Secondary Emergency Coordinator}

Jerry F. Bonn

Work: (702) 295-7341

Address: To be provided in field document
Pager: (702) 794-6325

Home: To be provided in field document

Net $3 \# 763$; Net $15 \# 813$ 


\section{Alternate Emergency Coordinator}

Curtis Obi

Address: To be provided in field document
Work: (702) 295-5577

Pager: (702) 794-6659

Home: to be provided in field document

Net 15: 820

\subsection{RESPONSIBILITIES}

The ECs have the authority to commit the necessary resources to implement this plan. Personnel resources will be applied consistent with the requirements of Title 29 CFR $\S 1910.120$ (Occupational Safety and Health Administration, 1996). The ECs will remain thoroughly familiar with the following:

- All aspects of this Plan.

- All operations and activities under control at the Pesticide Release Site.

- The locations and characteristics of the wastes handled.

- The locations of all the records.

- $\quad$ The Pesticide Release Site layout.

In the event of an emergency, the EC will be responsible for the following:

- $\quad$ Stopping all operations, where applicable.

- $\quad$ Implementing this Plan.

- $\quad$ Contacting the Communication Information Center (CIC) through the MAYDAY/911 system and making notification of the emergency.

- $\quad$ Notifying all pertinent personnel of the emergency. 
- $\quad$ Acting as the incident coordinator.

- Attempting to stop, slow, or dike the discharge if it can be done safely with the materials at hand.

- $\quad$ Providing the technical expertise necessary so that all responders are fully informed of the potential hazards.

The secondary EC will also be responsible for preparing, posting, and maintaining an emergency information sheet which provides the emergency response information such as telephone number for emergency response teams. The secondary $\mathrm{EC}$ is also responsible for personnel evacuation. In the event that the secondary EC is not available the alternate EC will conduct these duties. Because the alternate EC is also the Site Supervisor and will be on-site most times, the alternate EC will take primary responsibility until the EC arrives on-site.

\subsection{NOTIFICATION}

The first person who becomes aware of an emergency at the Pesticide Release Site shall immediately notify the proper authorities. Initial notification should be to their supervisor. If the emergency involves only a release of hazardous materials, the supervisor shall contact the EC who will initiate the necessary notification.

When the nature of the emergency is a fire, explosion, or involves personnel injury, the supervisor shall immediately notify the CIC via the MAYDAY/911 system. The CIC shall notify the Fire Protection Services Section and/or medical personnel, as required. The supervisor shall contact the EC.

If the first person to become aware of an emergency is not an ER employee and there are no ER personnel in the area, that person should follow the notification instructions posted at the perimeter of the Pesticide Release Site.

\subsection{RESPONSE PROCEDURES}

There are two general classifications of incidents that could occur at the Pesticide Release Site: fire and/or explosions and a spill of potentially hazardous materials. The initial response will be to protect human health and safety, and then the environment. The following actions will be taken: 
C Work in the area will cease immediately.

C For fire: Contact the CIC by using the Net MAYDAY/911 system. In the case of a small, controllable fire, an ABC-type fire extinguisher can be used. If a fire extinguisher is used, still contact the CIC for follow-up requirements.

For spill: $\quad$ Attempt to stop, slow, or dike the discharge without compromising health and safety.

C Notify the EC who will obtain additional emergency response assistance as required.

C Remove injured persons and administer first aid as required.

C Complete appropriate documentation (Figure 3).

\subsection{EVACUATION PLAN}

Notification for personnel to evacuate the area will be received by an emergency signal. The EC will be in possession of a blow-horn or similar device that will signal all workers to leave the area and gather in the designated assembly area. Evacuation notification will be discussed in the tailgate safety briefings. All radio nets will be kept clear and be used to transmit emergency information only. The EC will be accountable for all personnel. The assembly area for evacuated personnel will be at the field office. If cover must be taken, personnel will be instructed to enter the field trailer or field vehicles.

\subsection{EMERGENCY DECONTAMINATION AND FIRST AID}

If a worker is contaminated with a chemical substance, direct the worker to proceed at once to a temporary decontamination area and drench the worker with copious amounts of water. Pay particular attention to the victim's eyes and face. Do not remove personal protective equipment 


\section{Bechtel Nevada \\ INJURY/LLNESSINCIDENT REPORT}

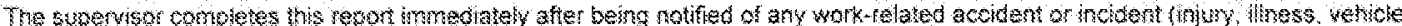

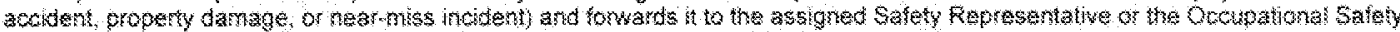

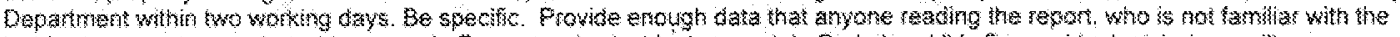

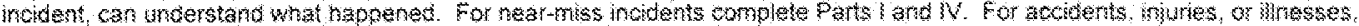

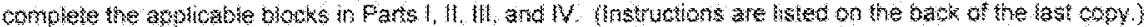

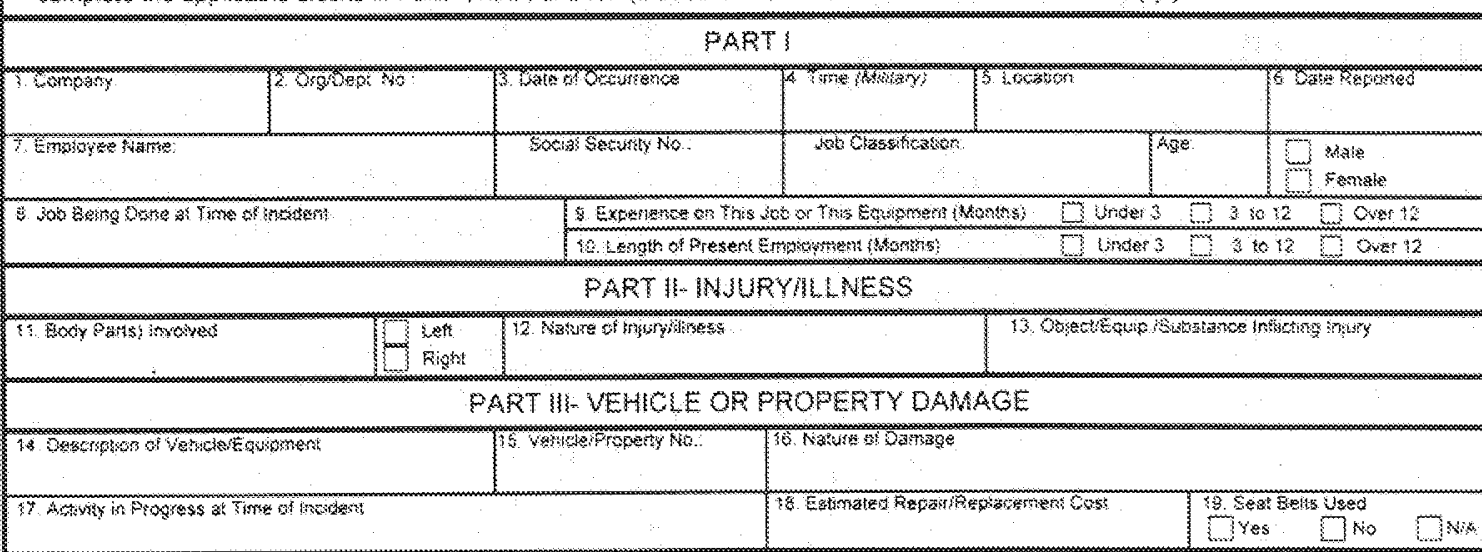

PART IV - DESTRRFTON OF EVENTS ANAL YSIS OF CAUSES AND ACTIONS TO BREVENT RECURRENCE

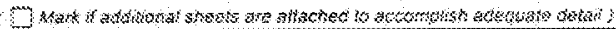

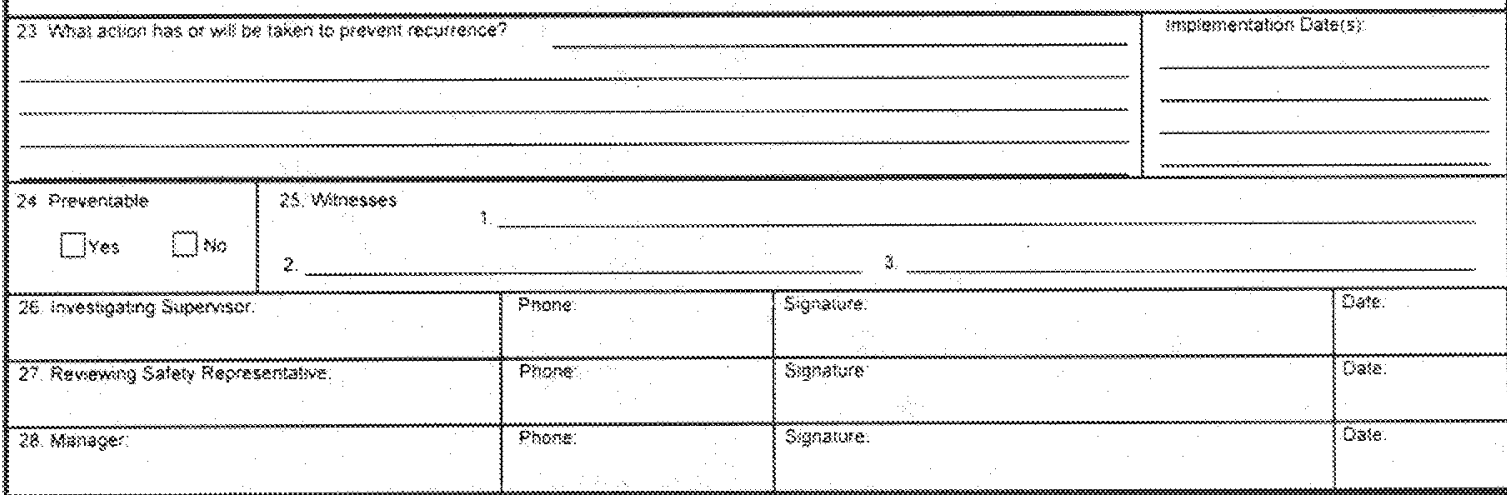

FOURE 3

INUURYILLNESS/NCIDENT REPORT 
(PPE) until all contamination has been thoroughly rinsed off. Contact the CIC for assistance and advice. Move the victim to fresh air.

\subsection{CLEAN UP}

Clean up of potential hazardous waste will be conducted by personnel having the appropriate training and PPE as determined by the EC. Clean up will meet all current applicable standards and regulations. 


\subsection{EMERGENCY SERVICES}

\subsection{ON-SITE CONDITION OF EMERGENCY SERVICES}

No coordination agreement with off-site organizations has been made because services are available on-site to respond to all credible emergencies. These services include the NTS Fire Protection and Emergency Medical Services, medical services, laboratory services, and radiological and Industrial Hygiene services. These services are linked to the CIC and have the capability to respond to emergencies involving hazardous, radioactive, or mixed waste constituents.

\subsection{MEDICAL SERVICES}

Medical support for emergencies is available from the Fire Protection and Emergency Medical Services Section of BN. BN Occupational Medicine (BNOM), located in Building 650, Mercury, provides physician and nurse care for minor illnesses and injuries during normal (daytime) working hours, Monday through Thursday. BNOM supports the efforts of the Fire Protection and Emergency Medical Services Section in times of emergencies. Occupational Medicine also supports the Fire Protection and Emergency Medical Services Section with coordination of patient care with Las Vegas-based hospital providers. All health care professionals employed by BNOM meet state and local licensing and certification requirements.

\subsection{FIRE PROTECTION AND EMERGENCY MEDICAL SERVICES}

The NTS Fire Station located in Mercury serves the NTS 24 hours a day, seven days a week. The Fire Station is located approximately 2.4 kilometers ( 1.5 miles) from the work location. The Area 6 fire Station serves the NTS 10 hours a day, Monday through Thursday.

Emergency Medical Services are available through the NTS Fire station in Mercury 24 hours a day, seven days a week. Emergency Medical Services are also available at the Area 6 Fire Station 24 hours a day, Monday through Friday starting at 0700. 


\subsection{EMERGENCY EQUIPMENT}

Emergency equipment includes equipment for fire control, emergency communications, spill control and cleanup, personnel protection, and first aid. The on-site emergency equipment is inspected monthly to ensure there is adequate inventory and that it is in good working order. Extra PPE, respiratory equipment, and environmental monitoring equipment are available. A list of the available equipment and the location(s) they can be found in Table 1.

TABLE 1- LIST OF AVAILABLE EQUIPMENT AND LOCATION.

\begin{tabular}{|c|c|c|}
\hline EQUIF & MENT & LOCATION \\
\hline Fire Extinguishers & & At entrance to exclusion zone; in excavation equipment \\
\hline First Aid Kits & & Each Vehicle, Office \\
\hline Eye Wash Station & & At exclusion zone access area \\
\hline $\begin{array}{l}\text { PPE: } \\
\text { Tyvek } \\
\text { Nitrile Gloves } \\
\text { Rubber Boots } \\
\text { Rain Suits } \\
\end{array}$ & $\begin{array}{l}\text { HEPA/Organic Vapor } \\
\text { Respirators } \\
\text { Face Shield } \\
\text { Safety Glasses }\end{array}$ & Office or Designated Field Vehicle \\
\hline Portable Net 15 Radios & & Office and Site Supervisor Vehicle \\
\hline $\begin{array}{l}\text { Spill Response Materials: } \\
\text { Horn } \\
\text { 55-gallon drums } \\
\text { Spill Kit } \\
\text { Absorbent Pads } \\
\end{array}$ & & Office or Designated Field Vehicle \\
\hline $\begin{array}{l}\text { Miscellaneous: } \\
\text { Garbage Bags } \\
\text { Buckets } \\
\text { Brushes } \\
\text { Soap } \\
\end{array}$ & $\begin{array}{l}\text { Kimwipes } \\
\text { Plastic } \\
\text { Sandbags } \\
\text { Duct Tape } \\
\end{array}$ & Office or Designated Field Vehicle \\
\hline
\end{tabular}




\subsection{REFERENCES}

BN, see Bechtel Nevada

Bechtel Nevada, 1996, “Accidents/Incident Notifying, Investigating, and Reporting," BN Safety Procedure M-A11-007, Las Vegas, NV.

Desert Research Institute, 1986, Daily. Seasonal, and Annual Precipitation at the Nevada Test Site. Nevada, Las Vegas, NV

EPA, see U.S. Environmental Protection Agency

Occupational Safety and Health Administration, 1996, Title 29 CFR § 1910.120, "Hazardous Waste Operations and Emergency Response," Washington, D.C.

U.S. Department of Energy, Nevada Operations Office, 1998, Corrective Action Decision Document for CAU 340: Pesticide Release Site, Nevada Test Site, Nevada, DOE/NV--525, Las Vegas, NV.

U.S. Environmental Protection Agency, 1996a, Title 40 Code of Federal Regulations 261.24, "Toxicity Characteristic," Washington, D.C.

U.S. Environmental Protection Agency, 1996b, Region IX Preliminary Remediation Goals (PRGs), San Francisco, CA. 


\section{THIS PAGE INTENTIONALLY LEFT BLANK}


APPENDIX C

PROJECT ORGANIZATION 


\section{THIS PAGE INTENTIONALLY LEFT BLANK}


The following are the DOE/NV project contacts:

Runore C. Wycoff

Division Director

Environmental Restoration Division

U.S. Department of Energy, Nevada Operations Office

P.O. Box 98518

Las Vegas, NV 89193-8518

(702) 295-0250

Janet L. Appenzeller-Wing

Project Manager

Industrial Sites Project

U.S. Department of Energy, Nevada Operations Office

P.O. Box 98518

Las Vegas, NV 89193-8518

(702) 295-0461

The identification of the project Health and Safety Officer and the Quality Assurance Officer can be found in the appropriate DOE plan. However, personnel are subject to change and it is suggested that the Project Manager be contacted for further information. The Task Manager will be identified in the FFACO Biweekly Activity Report prior to the start of field activities. 


\section{THIS PAGE INTENTIONALLY LEFT BLANK}




\section{DISTRIBUTION LIST}




\section{THIS PAGE INTENTIONALLY LEFT BLANK}




\section{DISTRIBUTION LIST}

*Provide copy of initial distribution of Revision 0; remainder of list gets Revision 0 if approved without changes. The entire list receives Revision 1, if issued.

\section{Nevada Department of Environmental Protection}

Paul Liebendorfer

Bureau of Federal Facilities

Division of Environmental Protection

333 W. Nye Lane, Room 13B

Carson City, NV 89706-0866

Mike McKinnon, Las Vegas Office

Bureau of Federal Facilities

Division of Environmental Protection

555 E. Washington, Suite 4300

Las Vegas, NV 89010

\section{U.S. Department of Energy}

Janet Appenzeller-Wing

1 (Uncontrolled)*

Environmental Restoration Division

U.S. Department of Energy, Nevada Operations Office

P.O. Box 98518 M/S 505

Las Vegas, NV 89193-8518

Clayton Barrow

Environmental Restoration Division

U.S. Department of Energy, Nevada Operations Office

P.O. Box $98518 \mathrm{M} / \mathrm{S} 505$

Las Vegas, NV 89193-8518
2 (Controlled)*

1 (Controlled)* 


\section{DISTRIBUTION LIST (Continued)}

Sabrina Lawrence

1 (Controlled)*

Environmental Restoration Division

U.S. Department of Energy, Nevada Operations Office

P.O. Box $98518 \mathrm{M} / \mathrm{S} 505$

Las Vegas, NV 89193-8518

DOE Public Reading Facility

1 (Controlled)

P.O. Box $98521 \mathrm{M} / \mathrm{S}$ NLV040

Las Vegas, NV 89193-8521

DOE/Nevada Operations Office

1 (Uncontrolled)

Technical Information Resource Center

P.O. Box $98521 \mathrm{M} / \mathrm{S} 505$

Las Vegas, NV 89193-8521

U.S. Department of Energy

Office of Scientific and Technical Information

175 Oak Ridge Turnpike

P.O. Box 62

Oak Ridge, TN 37831-0062

\section{Bechtel Nevada}

Correspondence Control

1 (Uncontrolled)*

Bechtel Nevada

P.O. Box $98521 \mathrm{M} / \mathrm{S}$ NLV008

Las Vegas, NV 89193-8521

Jerry Bonn

1 (Uncontrolled)*

Bechtel Nevada

P.O. Box $98521 \mathrm{M} / \mathrm{S}$ NTS306

Las Vegas, NV 89193-8521 


\section{DISTRIBUTION LIST (Continued)}

David Cowser

1 (Uncontrolled)*

Bechtel Nevada

P.O. Box $98521 \mathrm{M} / \mathrm{S}$ NLV082

Las Vegas, NV 89193-8521

Ann Heidema

1 (Uncontrolled)

Bechtel Nevada

P.O. Box 98521 M/S NLV022

Las Vegas, NV 89193-8521

Wayne Johnson

1 (Uncontrolled)*

Bechtel Nevada

P.O. Box $98521 \mathrm{M} / \mathrm{S}$ NTS306

Las Vegas, NV 89193-8521

Kenneth McGlothlin

1 (Uncontrolled)

Bechtel Nevada

P.O. Box $98521 \mathrm{M} / \mathrm{S}$ NTS330

Las Vegas, NV 89193-8521

Steve Nacht

1 (Uncontrolled)*

Bechtel Nevada

P.O. Box $98521 \mathrm{M} / \mathrm{S}$ NTS306

Las Vegas, NV 89193-8521

Curtis Obi

1 (Uncontrolled)*

Bechtel Nevada

P.O. Box 98521 M/S NTS306

Las Vegas, NV 89193-8521

Rick Remington

1 (Uncontrolled)

Bechtel Nevada

P.O. Box $98521 \mathrm{M} / \mathrm{S}$ NTS405

Las Vegas, NV 89193-8521 


\section{DISTRIBUTION LIST (Continued)}

Craig Stowell

1 (Uncontrolled)

Bechtel Nevada

P.O. Box 98521 M/S NTS110

Las Vegas, NV 89193-8521

\section{IT Corporation}

Brad Jackson

1 (Uncontrolled)*

IT Corporation

P.O. Box 93838

Las Vegas, NV 89193-8521

Rosa Silver

2 (Controlled)

IT Corporation

P.O. Box 93838

Las Vegas, NV 89193-8521 
NEVADA DIVISION OF ENVIRONMENTAL PROTECTION DOCUMENT REVIEW SHEET 


\section{THIS PAGE INTENTIONALLY LEFT BLANK}


Document Title/Number: Draft Corrective Action Plan (CAP) for Corrective Action Unit 340. Pesticide Release Site. Nevada Test Site.

Nevada

Document Date: July 8, 1999

Revision Number: 0

Originator/Organization: Bechtel Nevada

Date Comments Due: August 16, 1999

Reviewer/Organization: Nevada Division of Environmental Protection - Reference letter from Michael McKinnon to Runore Wycoff dated August 20, 1999.

\begin{tabular}{|c|c|c|c|c||}
\hline \hline $\begin{array}{c}\text { Comment } \\
\text { Number/ } \\
\text { Location }\end{array}$ & Type $^{\mathrm{a}}$ & & Comment & Accept \\
\hline \hline $\begin{array}{c}\text { 1. Executive } \\
\text { Summary } \\
\text { Page ix } \\
\text { 6th paragraph }\end{array}$ & & $\begin{array}{l}\text { c...verify that the pesticides have been removed..." } \\
\text { Add "hydrocarbons" to this sentence; ie., “...verify } \\
\text { that the pesticides and hydrocarbons have been } \\
\text { removed..." }\end{array}$ & Comment incorporated into text. & \\
\hline
\end{tabular}


DOCUMENT REVIEW SHEET

\begin{tabular}{|c|c|c|c|c|}
\hline $\begin{array}{l}\text { Comment } \\
\text { Numberl } \\
\text { Location } \\
\end{array}$ & Type $^{a}$ & Comment & Comment Response & Accept \\
\hline 2.General & & $\begin{array}{l}\text { Throughout this document, it is stated the } \\
\text { hydrocarbon-burdened soils will be disposed of in a } \\
\text { dedicated waste cell into the Area } 23 \text { Landfill. } \\
\text { Although the Area } 23 \text { Landfill is not permitted to } \\
\text { receive hydrocarbon-burdened soils, it appears the } \\
\text { soils in question are burdened with weathered, long- } \\
\text { chain hydrocarbons (diesel range and longer) versus } \\
\text { the more environmentally-unfriendly shorter-chain } \\
\text { hydrocarbons. In addition, since the proximity of the } \\
\text { Are } 23 \text { Sanitary landfill is such that disposing of these } \\
\text { soils here would result in significant cost savings over } \\
\text { disposal in the Area } 6 \text { Hydrocarbon Landfill, NDEP } \\
\text { concurs with DOE's proposal and will authorize } \\
\text { disposal (of) these soils in the Area } 23 \text { facility. Please } \\
\text { understand this decision was based on site-specific } \\
\text { conditions and does not constitute a precedent for } \\
\text { disposing of hydrocarbon-burdened soils in Area } 23 \text {. }\end{array}$ & $\begin{array}{l}\text { Bechtel Nevada Waste Management has recently } \\
\text { indicated that a dedicated cell for disposing of the } \\
\text { waste is not feasible or warranted. In addition, } \\
\text { since the waste stream is approved for disposal } \\
\text { into the sanitary landfill, survey points or markers } \\
\text { will not be placed. } \\
\text { Waste Management also prefers that the } \\
\text { hydrocarbon-burdened waste be transported to } \\
\text { the Area } 6 \text { hydrocarbon Landfill. This does not } \\
\text { have a significant cost impact as the estimated } \\
\text { volume is only approximately } 40 \text { cubic yards and } \\
\text { the disposal effort can likely be coordinated with } \\
\text { the loading of clean backfill soils from Area } 6 \text {. }\end{array}$ & \\
\hline 3. Appendices & & $\begin{array}{l}\text { According to the NDEP/DOE-approved Standard } \\
\text { outline for Corrective Action Plans, appendices are to } \\
\text { include Engineering Specifications and Drawings (A1) } \\
\text { and the Sampling and Analysis Plan (A2). This draft } \\
\text { CAP contains neither. }\end{array}$ & $\begin{array}{l}\text { Engineering specifications and drawings are not } \\
\text { warranted for this CAP as there is no } \\
\text { construction or engineered cover requirements. } \\
\text { The sampling and analysis requirements for the } \\
\text { site are detailed in Section } 2.4 \text { "Clean-Up } \\
\text { Verification." Therefore, these appendices are } \\
\text { not applicable to include in this document. } \\
\text { Section } 1.3 \text { "Corrective Action Plan Contents" } \\
\text { has been rewritten to address the rational for not } \\
\text { including Appendices A1 and A } 2 \text { in the CAP. }\end{array}$ & \\
\hline
\end{tabular}

